\title{
Ground-Water Geology \\ of Karnes County, Texas
}

GEOLOGICAL SURVEY WATER-SUPPLY PAPER 1539-G

Prepared in cooperation with the Texas Board of Water Engineers and the San Antonio River Authority

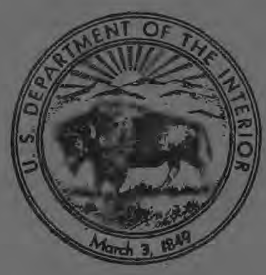


iAY 141963

Ground-Water Geology

of Karnes County, Texas

By R. B. ANDERS

CONTRIBUTIONS TO THE HYDROLOGY OF THE UNITED STATES

GEOLOGICAL SURVEY WATER-SUPPLY PAPER 1539-G

Prepared in cooperation with the Texas Board of Water Engineers and the San Antonio River Authority

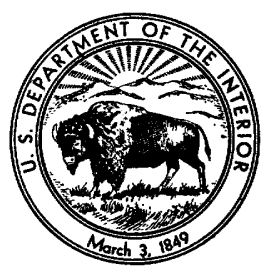


UNITED STATES DEPARTMENT OF THE INTERIOR

STEWART L. UDALL, Secretary

\section{GEOLOGICAL SURVEY}

Thomas B. Nolan, Director 


\section{CONTENTS}

Abstract.
Introduction
Purpose and scope of investigation
Economic development
Pre vious investigations
Acknowledgments
Climate

General geology

Geologic formations and the occurrence of ground water........ 12

Tertiary system

Paleocene series

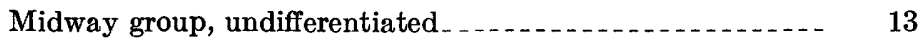

Eocene series....

Wilcox group, undifferentiated.

Claiborne group.......... 14

Carrizo sand

Mount Selman formation

Reklaw member.... 15

Queen City sand member

Weches greensand member

Sparta sand................. 16

Cook Mountain formation.

Yegua formation.

Jackson group, undifferentiated............ 17

Oligocene(?) series

Frio clay

Miocene(?) series.... 18

Catahoula tuff

Miocene series

Oakville sandstone

Miocene(?) series.

Lagarto clay ........... 19

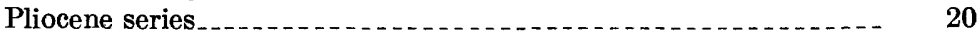

Goliad sand

Tertiary (?) system

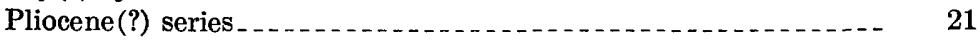

Interstream sand and gravel deposits

Quaternary system . . . 21

Pleistocene and Recent series............. 21

Alluvium . .

Aquifer tests......... 22 
Page

Ground-water development.

Present development._.

Withdrawals ................. 23

Changes in water level. 23

Potential development.

Surface-water development._. 29

Quality of water 30

Summary of conclusions._. 35

Selected references._. 36

Index

\section{ILLUSTRATIONS}

[Plates are in pocket]

Plate 1. Geologic map of Karnes County, Tex., showing location of wells.

2. Annual precipitation at Karnes City and Runge.

3. Annual evaporation and precipitation at Beeville, Bee County.

4. Geologic cross sections $A-A^{\prime}, B-B^{\prime}$, and $C-C^{\prime}$.

5. Geologic cross section $D-D^{\prime}$.

6. Geologic cross section $E-E^{\prime}$.

7. Geologic cross section $F-F^{\prime}$.

8. Thickness of sand containing fresh to slightly saline ground water, Karnes County.

9. Monthly mean discharge of San Antonio River near Falls City.

10. Monthly mean discharge of Cibolo Creek near Falls City.

Figure 1. Index map of Texas showing location of Karnes County

2. Location of climatological stations, aquifer-test sites, and stream-gaging stations in Karnes and adjoining counties..-

3. Mean monthly precipitation at Karnes City and Runge.....-

4. Mean monthly temperature, precipitation, and evaporation at Beeville, Bee County.....

5. Monthly pumpage from municipal wells at Falls City, Runge, Karnes City, and Kenedy

6. Relation between drawdown and transmissibility in an aquifer of infinite areal extent.

7. Theoretical drawdown along a profile between a pumping well and a line source. 


\section{TABLES}

TABLE 1. Well and spring numbers used in this report and corresponding numbers used in the report by Shafer (1937) ............

Page

2. Stratigraphic units and their water-bearing properties in Karnes County

3. Results of aquifer tests 10

4. Water levels in selected wells in 1936 or 1937 and water levels in the same wells in 1955 or 1956 


\title{
CONTRIBUTIONS TO THE HYDROLOGY OF THE UNITED STATES
}

\section{GROUND-WATER GEOLOGY OF KARNES COUNTY, TEXAS}

\author{
By R. B. ANDERs
}

\begin{abstract}
The exposed rocks and those underlying Karnes County dip toward the Gulf of Mexico at average rates ranging from 20 to more than 200 feet per mile. The oil fields are on structures associated with faulting; the effect of faulting on the occurrence of ground water has not been determined.

The principal water-bearing formations, from oldest to youngest, underlying the county are the Carrizo sand, Yegua formation, Jackson group, Catahoula tuff, Oakville sandstone, and Lagarto clay. They range in age from Eocene to Miocene and all are of sedimentary origin. About 40 million acre-feet of usable water (water containing less than $3,000 \mathrm{ppm}$ ) is stored more then 2,500 feet below land surface in the Carrizo sand; 30 million acre-feet is stored in the younger formations at depths less than 1,000 feet.

Ground-water withdrawals for municipal, industrial, and domestic use averaged about 1.7 million gpd in 1957. Irrigation and stock supplies were derived from both ground- and surface-water sources. In general, water levels from 1936 through 1957 were not affected appreciably by withdrawals.

Recharge to the ground-water reservoir from precipitation, although only a small percentage of total precipitation, exceeded withdrawals of ground water by wells in 1957.

Most of the usable ground water in Karnes County is of substandard quality; whereas water from the San Antonio River, although hard, is of excellent quality. Wells tapping the Carrizo may yield as much as $1,000 \mathrm{gpm}$ in the northwestern part of the county; wells in the shallower formations may yield as much as 600 $\mathrm{gpm}$ in the most favorable areas, but in some places may yield only a few gallons per minute of water suitable only for stock.
\end{abstract}

\section{INTRODUCTION \\ PURPOSE AND SCOPE OF INVESTIGATION}

This investigation, whose purpose was to provide up-to-date information concerning the occurrence, quality, development, and availability of ground water in Karnes County was begun in the fall of 1955 by the U.S. Geological Survey at the request of, and in cooperation with, the San Antonio River Authority and the Texas Board of 
Water Engineers. The objectives of the investigation were (1) to study the geology as it pertains to the occurrence of ground water; (2) to determine the areal extent, depth, thickness, and water-bearing properties of the strata containing fresh to slightly saline water; (3) to determine the chemical quality of the ground water; (4) to estimate the quantity of water stored in the ground-water reservoir; (5) to determine the sources and areas of recharge to aquifers; (6) to determine the present and estimate the future development of ground water; and (7) to prepare a summary of the surface-water resources of the county.

The report includes data collected from the fall of 1955 through the fall of 1956, and is based on records of 404 wells, 11 drillers' logs, and 340 chemical analyses of water samples. Most of the water samples were analyzed in 1937 and reported by Shafer (1937).

For convenience in identifying the wells within the county, a grid based on lines of latitude and longitude was constructed on the geologic map (pl. 1). The quadrangles in the grid are identified by letters of the alphabet, and the wells are numbered consecutively in each quadrangle.

A geologic map based on a compilation of current studies and previously published maps was prepared. The subsurface geology is shown by six geologic cross sections prepared from electric logs. The water-yielding properties of the formations were tested at six sites.

The investigation was under the immediate supervision of $R$. W. Sundstrom, district engineer of the Geological Survey in charge of ground-water investigations in Texas, and under the administrative direction of S. W. Lohman, branch area chief.

\section{LOCATION AND PHYSICAL FEATURES}

Karnes County is on the west Gulf Coastal Plain in south-central Texas (fig. 1). The county seat, Karnes City, is 55 miles southeast of San Antonio. The area of the county is 758 square miles.

Parts of Karnes County are nearly flat, but most of the county is rolling to moderately hilly. The altitude ranges from about 550 feet in the northwestern part of the county to 170 feet in the southeastern part, where the San Antonio River crosses the Goliad County line. The county is drained mainly by the San Antonio River and its main tributary, Cibolo Creek, both of which are perennial streams. The southwestern part of the county is drained by intermittent tributaries of the Atascosa River, and a few areas in the northeastern part are drained by minor tributaries of the Guadalupe River.

The two largest towns in Karnes County, Karnes City and Kenedy, had populations estimated to be 3,000 and 5,100, respectively, in 1955 . The total population of the county was about 18,000 in 1955 . The 


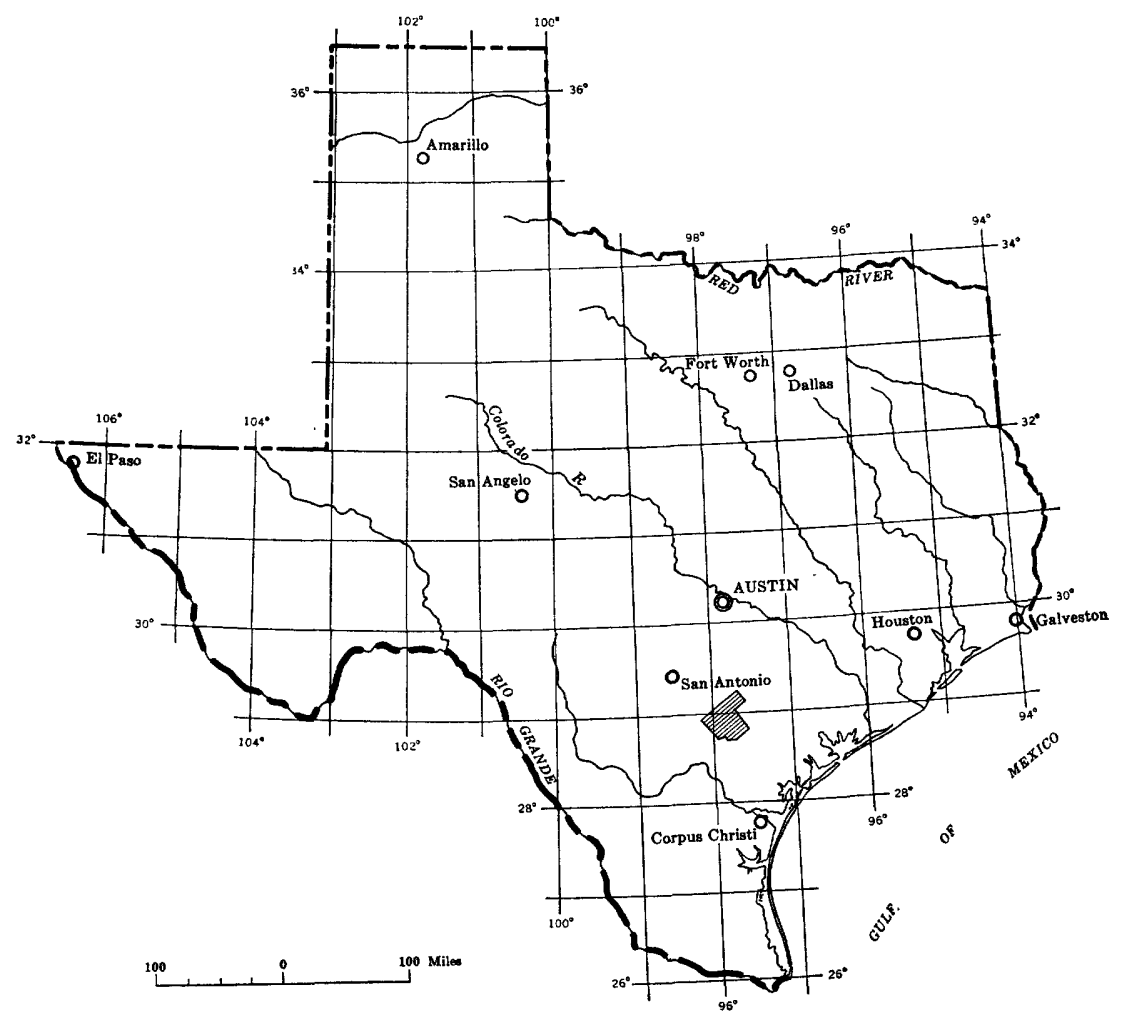

Figore 1.-Index map of Texas showing location of Karnes County.

oldest settlement, Panna Maria, was established by Polish immigrants in 1854 , the same year the county was created. Other communities in Karnes County include Runge, Falls City, Helena, Gillett, Coy City, Hobson, and Czestochowa.

\section{ECONOMIC DEVELOPMENT}

The economy of Karnes County is based upon farming, cattle ranching, and oil production. The principal crops are flax, corn, grain sorghums, and cotton. Other crops include peanuts, tomatoes, broomcorn, peas, beans, and several varieties of grasses. Ranching and dairying are practiced in the hilly areas and in areas where the soil is not suitable for cultivated crops. The production of oil has risen steadily since it started in the county in 1930; 2.7 million barrels of oil were produced in 1955. Uranium ore was discovered near the west corner of the county early in 1955. Since then, several other small bodies of ore have been discovered in Karnes and nearby counties. The deposits had not been mined by the end of 1957 . 
Drought was so severe that a few farmers drilled wells for irrigation. Before the introduction of irrigation wells in 1953, irrigation was practiced only along the banks of the San Antonio River. Most of the farming in Karnes County still is dependent upon precipitation for its water requirements.

\section{PREVIOUS INVESTIGATIONS}

Previous investigations relating to the water resources of Karnes County include a report by Shafer (1937), which contains records of 369 wells, 384 chemical analyses of water samples, drillers' logs of 12 wells and 156 shallow test holes, and a map showing well locations. Some of the more pertinent data from Shafer's report is reproduced in this report. Table 1 shows the well numbers used by Shafer and the corresponding numbers used in this report. Descriptions of geologic sections at several locations in Karnes and adjacent counties have been published in regional reports by Deussen (1924, p. 88, 92, 93) and Sellards, Adkins, and Plummer (1932, p. 688, 719, 720). A report by Eargle and Snider (1957) contains a description and geologic sections of the Jackson group in the west corner of the county; descriptions of the Frio clay, Catahoula tuff, and Oakville sandstone; and descriptions of major uranium deposits in Karnes, Atascosa, and Live Oak Counties. The public-water supplies of five towns in the county were described briefly by Broadhurst, Sundstrom, and Rowley (1950, p. 7-8, 75-79).

\section{ACKNOWLEDGMENTS}

The writer expresses his appreciation for information and assistance by officials of Kenedy, Karnes City, Runge, the United Pipeline Co., and by farmers and ranchers in the county. Considerable help also was received from well drillers George Gunther and Tom Moy and from officials of the Stanolind Oil Co., the Magnolia Petroleum Co., the Humble Oil \& Refining Co., and the Southern Minerals Corp. The writer is indebted to D. Hoye Eargle, of the Geologic Division of the U.S. Geological Survey, who mapped part of the contact between the Jackson group and the Catahoula tuff.

\section{CLIMATE}

The climate of Karnes County is subhumid. The mean daily temperature at Runge averages $54^{\circ} \mathrm{F}$ in January and $84^{\circ} \mathrm{F}$ in July. The maximum recorded temperature was $106^{\circ} \mathrm{F}$; the minimum was $6^{\circ} \mathrm{F}$. The record mean annual precipitation at Runge, the station having the longest period of record in Karnes County (1896-1956), is 28.94 inches. The only other record available in the area for a compa- 
TABLE 1.-Well and spring numbers used in this report and corresponding numbers used in the report by Shafer (1937)

\begin{tabular}{|c|c|c|c|c|c|c|c|}
\hline Old & New & old & New & Old & New & Old & New \\
\hline 2. & $\mathrm{C}-43$ & 136 . & B-16 & 251 & $\mathrm{G}-4$ & 409 & $\mathrm{E}-50$ \\
\hline & $\mathrm{C}-44$ & 137. & B-15 & 252 . & C-3 & 411 - & $\mathrm{D}-38$ \\
\hline 4 & $\mathrm{C}-47$ & 138 & B-14 & 253 & F-12 & 413 & G-19 \\
\hline $8 \ldots$ & $\mathrm{C}-40$ & 139. & $B \sim 9$ & 257 & $\mathrm{G}-52$ & 420 & $\mathrm{H}-2$ \\
\hline 10 . & $\mathrm{C}-26$ & 140 & B-6 & 262 & $\mathrm{G}-50$ & 421 & H-57 \\
\hline 11. & $\mathrm{C}-25$ & 143 & B-3 & 264 & $\mathrm{G}-49$ & 422 & $\mathrm{H}-7$ \\
\hline 13 & $\mathrm{C}-24$ & 144 & B-2 & 265 & $\mathrm{G}-26$ & 424 & $\vec{H}-56$ \\
\hline 14 & $\mathrm{C}-52$ & 148 & B-1 & 267 & $\mathrm{G}-10$ & 427. & $\mathrm{G}-37$ \\
\hline 15 & $\mathrm{C}-53$ & 150 & B-57 & 268 & $\mathrm{G}-54$ & 428 & $\mathrm{G}-35$ \\
\hline 17 & $\mathrm{C}-56$ & 152 & B-56 & $270_{-}$ & $\mathrm{G}-14$ & 433 & $\mathrm{G}-17$ \\
\hline 19 & $\mathrm{C}-4$ & 154 & B-55 & 272 & $\mathrm{G}-9$ & 435 & $\mathrm{G}-30$ \\
\hline 21 & $\mathrm{C}-5$ & 157. & B-53 & 273 & $\mathrm{G}-8$ & 436 & $\mathrm{G}-28$ \\
\hline 23 & $\mathrm{C}-8$ & 159 & B-49 & 274 & $\mathrm{G}-7$ & 441 & $\mathrm{G}-47$ \\
\hline 24 & $\mathrm{C}-11$ & 160 & B -50 & 275 & $\mathrm{G}-5$ & 444 & $\mathrm{G}-44$ \\
\hline 25 & $\mathrm{C}-10$ & 167 & B-45 & 276 & $\mathrm{G}-6$ & 445 & $\mathrm{G}-46$ \\
\hline 28 & $\mathrm{C}-23$ & $170_{-}$ & B -36 & 279 & D-27 & 447 . & $\mathrm{G}-32$ \\
\hline 29 & $\mathrm{C}-18$ & 171 & B-38 & 281 & $D-29$ & 448 & $\mathrm{G}-38$ \\
\hline 32 & $\mathrm{C}-12$ & 173. & B- 40 & 282 & $\bar{D}-28$ & 451 & $\vec{H}-59$ \\
\hline 34 & $\mathrm{C}-7$ & 174 & B- 35 & 283 & $\mathrm{D}-31$ & 453 & $\mathrm{G}-39$ \\
\hline 35 & $\mathrm{D}-20$ & 175 & B-39 & 285 & $\mathrm{D}-32$ & 454 & $\mathrm{G}-40$ \\
\hline 36 & D-19 & $177_{-}$ & B-24 & 287. & $\overline{\mathrm{D}}-\mathbf{3 3}$ & 457 & $\overrightarrow{\mathrm{H}}-65$ \\
\hline 39 & $\mathrm{C}-6$ & 180 & B-27 & 289 & $\bar{G}-15$ & 458 & $\mathrm{H}-66$ \\
\hline 45 & C-3 & 182 & B-26 & 290 . & $\mathrm{G}-13$ & 465 & $\mathrm{H}-69$ \\
\hline 52 & $\mathrm{D}-15$ & 184 & B-25 & 291 & $\mathrm{G}-12$ & 468 & $\mathrm{H}-51$ \\
\hline 53. & $\mathrm{D}-18$ & 186 & B- 29 & 292 & $\mathrm{G}-25$ & 469 & $\overline{\mathrm{H}}-52$ \\
\hline 54 & $\mathrm{D}-17$ & 188 & B-34 & 293 & $\mathrm{G}-24$ & 471. & $\vec{H}-5$ \\
\hline $55 a$ & $\mathrm{D}-16$ & $191_{-}$ & B-32 & 295 & $\mathrm{G}-16$ & 472 & $\overline{\mathrm{H}}-6$ \\
\hline 59. & $\mathrm{D}-10$ & 194 & B-28 & 297 & D-37 & 476 & $\overline{\mathbf{H}}-11$ \\
\hline 62. & $\mathrm{D}-11$ & 195 & B-30 & $300_{-}$ & $\mathrm{D}-34$ & 477 . & $\overrightarrow{\mathrm{H}}-10$ \\
\hline 65 & $\mathrm{D}-12$ & 197 & $\mathrm{E}-1$ & 301 & $\mathrm{D}-36$ & 481 & $\overrightarrow{\mathrm{H}}-12$ \\
\hline $66_{-}$ & D-13 & 198 & $\mathrm{D}-1$ & 310 . & D-48 & 482 & $\overrightarrow{\mathrm{H}}-13$ \\
\hline 67. & $\mathrm{D}-14$ & 203 & $\mathrm{D}-2$ & 311 & D-47 & 483 & $\overline{\mathrm{H}}-47$ \\
\hline 74 & A-15 & 204 & D-3 & 315 & $\mathrm{D}-52$ & 484 & $\overrightarrow{\mathrm{H}}-50$ \\
\hline 75 . & $\mathrm{A}-14$ & 209 & $\mathrm{D}-5$ & 322 & $\bar{D}-42$ & 485 & $\overline{\mathrm{H}}-46$ \\
\hline 77. & $\mathrm{~A}-13$ & 212 & $\mathrm{D}-7$ & 346 . & $\mathrm{E}-57$ & 486 & $\mathrm{H}-44$ \\
\hline 70 & $\mathrm{~A}-12$ & 213 & D-57 & 349 & $\mathrm{E}-3$ & 487 & $\overrightarrow{\mathrm{H}}-45$ \\
\hline 82 & D-6 & 214 & D-58 & 352 & $\mathrm{E}-4$ & $490_{-}$ & $\vec{H}-42$ \\
\hline 84 & $\mathrm{D}-4$ & 215 & D-55 & 355 & $\mathrm{E}-7$ & 491 & $\overrightarrow{\mathrm{H}}-\overline{33}$ \\
\hline 85 & A-10 & 218 & D-30 & 358 & $\mathrm{E}-8$ & 494 & $\overrightarrow{\mathbf{H}}-29$ \\
\hline & $A-11$ & 219 & $\mathrm{D}-21$ & 361 & $\mathrm{E}-10$ & 495 & $\mathrm{H}-28$ \\
\hline 92 . & $\mathrm{A}-16$ & 221 & $\mathrm{C}-22$ & 362 & $\mathrm{E}-9$ & 498 & $\overrightarrow{\mathrm{H}}-27$ \\
\hline 94 & A-17 & 223 & D-22 & 363 & $\bar{E}-55$ & $499_{-}$ & $\mathrm{E}-29$ \\
\hline 95 & A-18 & 224 & D-23 & $366_{-}$ & E-14 & 501 & $\mathrm{H}-38$ \\
\hline 100 & $\mathrm{~A}-6$ & 226 & D-25 & $367_{-}$ & E-15 & 502 & $\mathrm{H}-41$ \\
\hline 103 & A-9 & 227 & $\mathrm{D}-26$ & $376_{-}$ & E-17 & 503 & $\mathrm{H}-19$ \\
\hline 105 & A-7 & 228 & $\mathrm{C}-32$ & $377_{-}$ & $\mathrm{E}-18$ & 506 & H-17 \\
\hline 108 & $A-5$ & 229 & $\mathrm{C}-33$ & $385_{-}^{-}$ & $\mathrm{E}-43$ & 508 & $\mathrm{E}-34$ \\
\hline 110 & $A-4$ & 230 & C-31 & 388 & $\bar{E}-39$ & 510 & $\mathrm{H}-23$ \\
\hline 114 & $\mathrm{~A}-3$ & 231 & C-30 & 391 & $\mathrm{E}-23$ & 512 & $\mathrm{H}-22$ \\
\hline 116 & B-7 & 233 & $\mathrm{C}-27$ & 395. & $E-38$ & 513 & $\mathrm{H}-36$ \\
\hline 120 & B-8 & 234 & C-36 & 396 & $\mathrm{E}-37$ & 514 & $\mathrm{H}-25$ \\
\hline 121 . & B-12 & $235_{-}$ & $\mathbf{C}-35$ & 398 & $\mathrm{H}-16$ & 515 & $\mathrm{E}-32$ \\
\hline 122 & B-11 & 237 & F-3 & 399 & H-15 & 516 . & $\overline{\mathrm{E}}-28$ \\
\hline 126. & B-21 & $239_{-}$ & C- -38 & 400 & $\mathrm{H}-8$ & 518 & $\mathrm{E}-25$ \\
\hline 128 & B-22 & 243 & F-18 & 401 & $\mathrm{H}-\mathbf{3}$ & 520 & $\mathrm{E}-24$ \\
\hline 130 & $B-23$ & & $\mathbf{F}-4$ & 404 & $\mathrm{E}-44$ & 521 & $\mathrm{E}-3 \overline{5}$ \\
\hline 131. & B-20 & 245 & $\overline{\mathrm{F}}-\overline{5}$ & 405 & $\mathrm{E}-45$ & 522 & $\mathrm{E}-36$ \\
\hline & B-41 & 248 & F-9 & 406 & $\mathrm{E}-46$ & & \\
\hline & B-19 & 250 & $\mathrm{G}-1$ & 408 & $\mathrm{E}-49$ & & \\
\hline
\end{tabular}




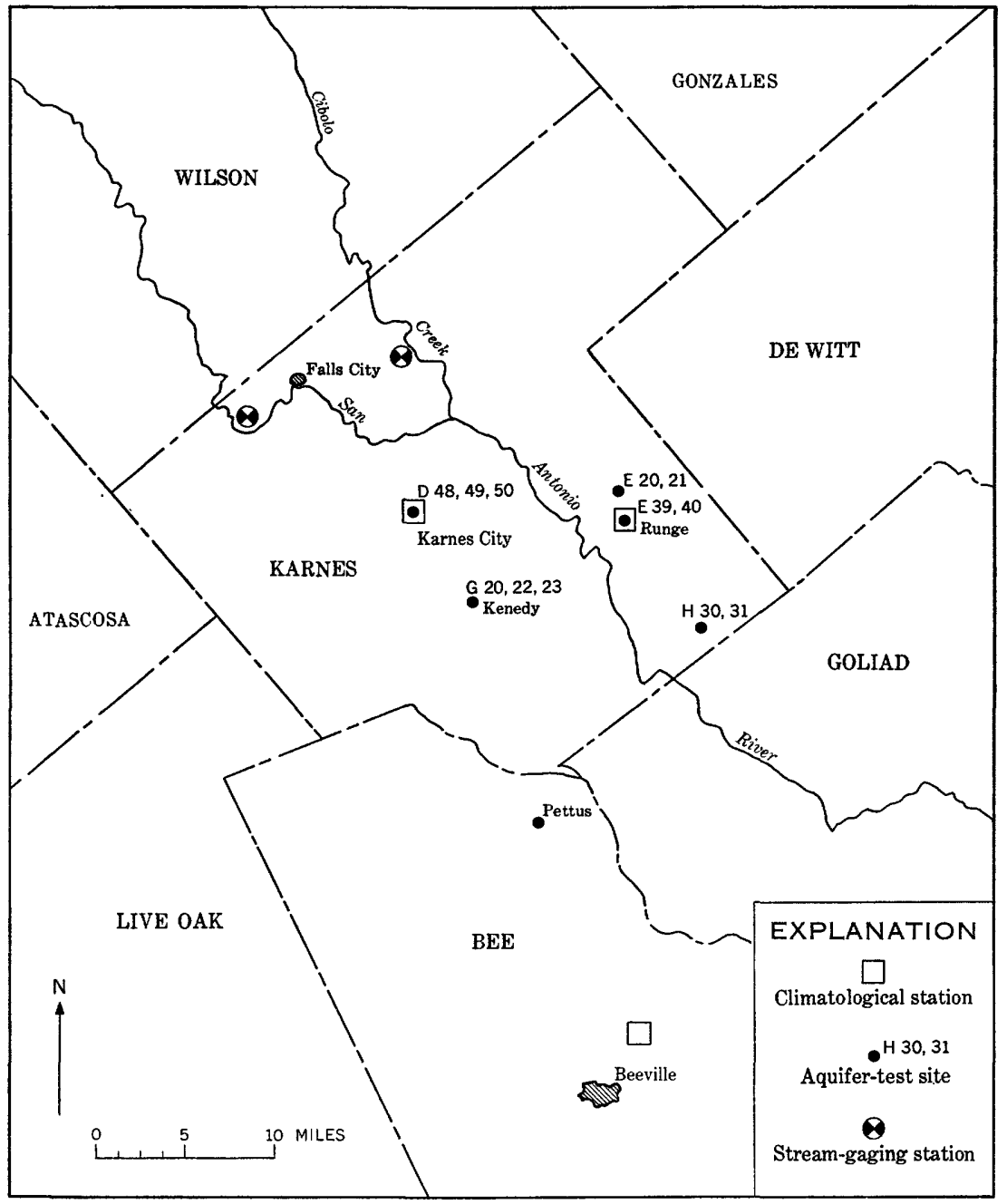

Figure 2.-Location of elimatological stations, aquifer-test sites, and stream-gaging stations in Karnes and adjoining counties, Texas.

rable period is from a station at Beeville in Bee County (fig. 2), where the record mean annual precipitation for 1896-1956 was 30.55 inches. Weather data from these stations and one at Karnes City are shown graphically on plates 2 and 3 and in figures 3 and 4 . Precipitation in Karnes County was below normal from 1950 through 1956. Although drought was relieved somewhat in 1952, when above-normal precipitation was recorded at Runge, the prolonged drought had been so severe that the county was declared a disaster area by the President on June 29, 1953. Dryfarming continued through the drought, but many crops were damaged and several complete crop failures were reported. 

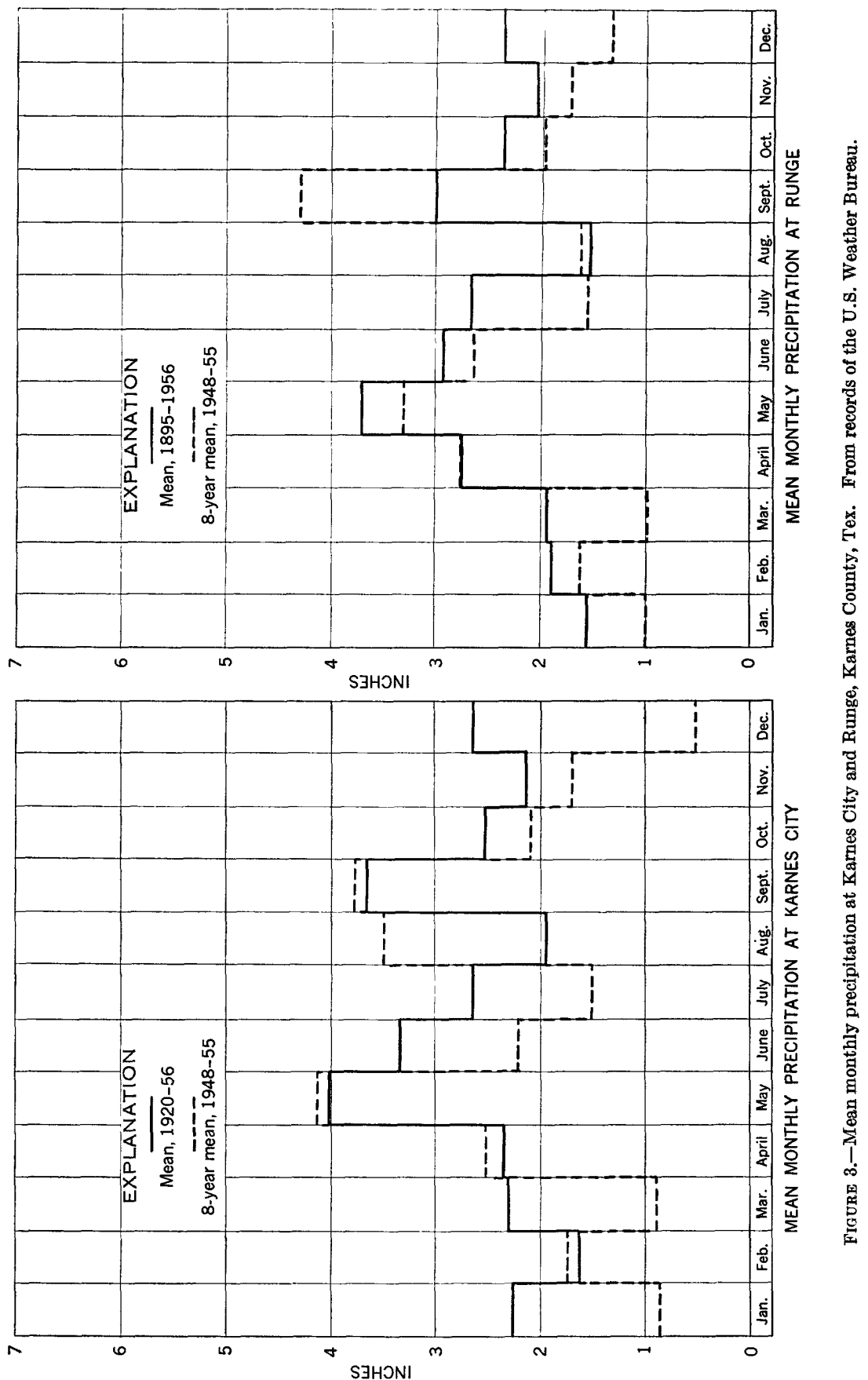
G8 CONTRIBUTIONS TO THE HYDROLOGY OF THE UNITED STATES
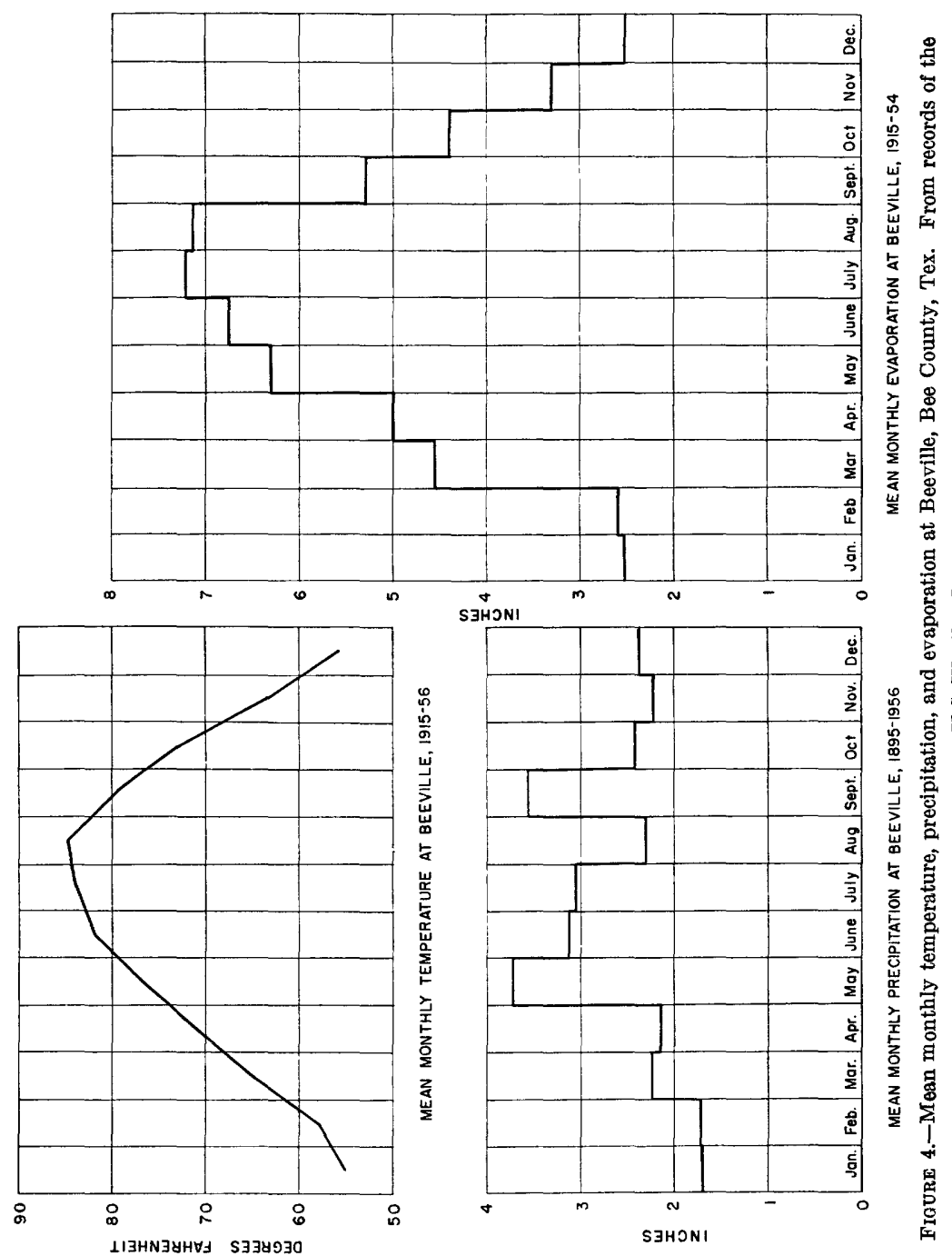

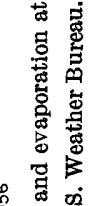


One part of the county in a particular year may suffer from drought, whereas another part may have an abundance of rainfall. The amount of precipitation for periods of a few years may vary appreciably from station to station. The maximum recorded difference in annual precipitation between the stations at Beeville and Runge was 15.7 inches in 1925 and 1932, and between the stations at Beeville and Karnes City it was 24.4 inches in 1935. Although the differences in precipitation between stations may be great for certain years, the greatest difference in the mean annual precipitation of record for the 3 stations is only 2.5 inches.

The severity of the drought is demonstrated by comparing the mean monthly precipitation for the period of record with the 8-year means from 1948 through 1955 . Figure 3 shows that generally the mean monthly precipitation for the short period was substantially less than for the period of record.

Evaporation rates during a drought generally are greater than during a period of normal or above normal precipitation. Records of the rate of evaporation in Karnes County are not available; however, records from the Beeville station in the adjoining county, shown on plate 3 , show that the annual evaporation was above normal from 1950 through 1954. The records from 1955 through 1956 are not comparable directly because the evaporation-measuring equipment was changed; however, they suggest that the annual evaporation from 1955 through 156 also was above normal.

\section{GENERAL GEOLOGY}

Geologic formations in Karnes County range in age from Paleocene to Recent. Thickness, lithology, and water-bearing characteristics of geologic formations are shown in table 2. Areal geology and location of selected wells are shown on plate 1. Structure, lithology, and thickness of the formations are shown on six geologic cross sections based on electric logs (pls. 4-7).

The formations strike northward in the southwestern part of Karnes County and northeastward in the remainder of the county. The strike of younger formations is more nearly north than that of older formations.

The formations dip toward the Gulf of Mexico at average rates ranging from 20 to more than 200 feet per mile. The dip of the older formations is slightly greater than that of the younger.

Rocks in Karnes County are cut by many normal faults, only a few of which are shown on plate 1. Most of the faults strike approximately parallel to the strike of the beds; however, a few strike diagonally across the strike of the beds. The faults dip steeply and have 
G10 CONTRIBUTIONS TO THE HYDROLOGY OF THE UNITED STATES

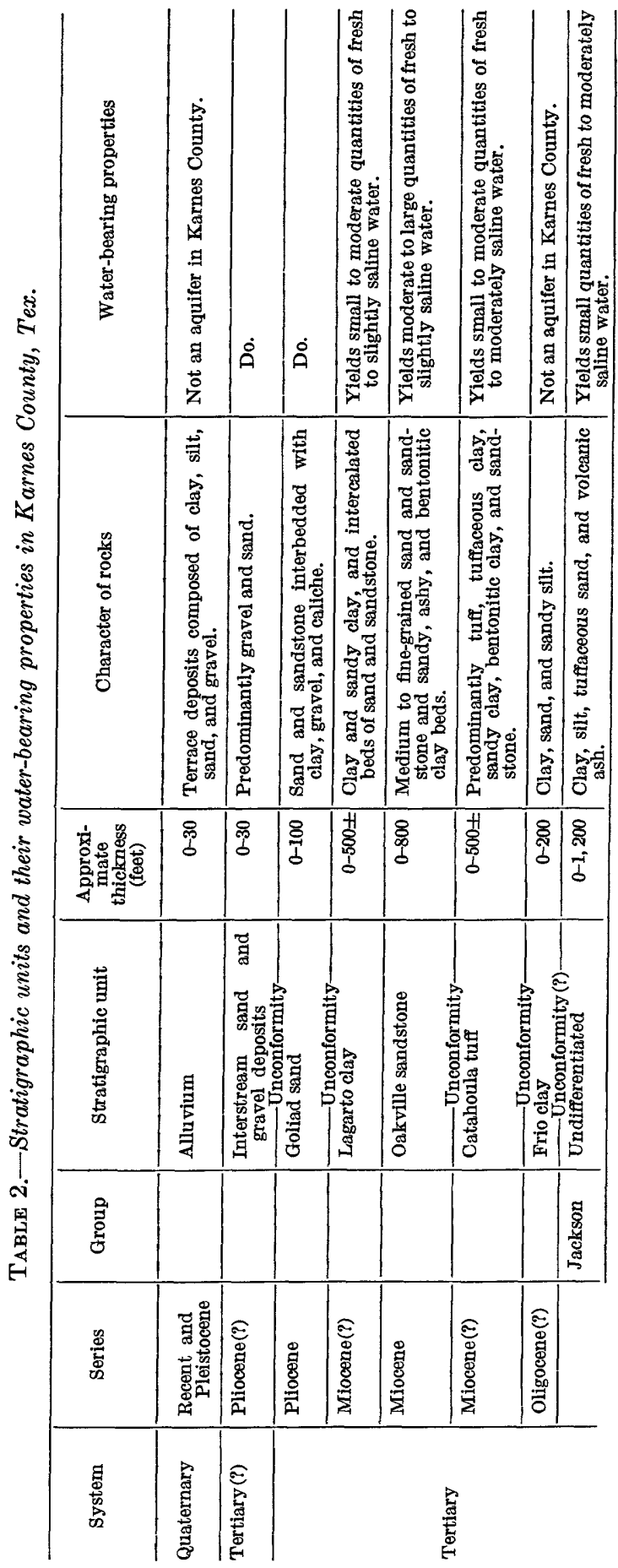


GROUND-WATER GEOLOGY OF KARNES COUNTY, TEXAS G11
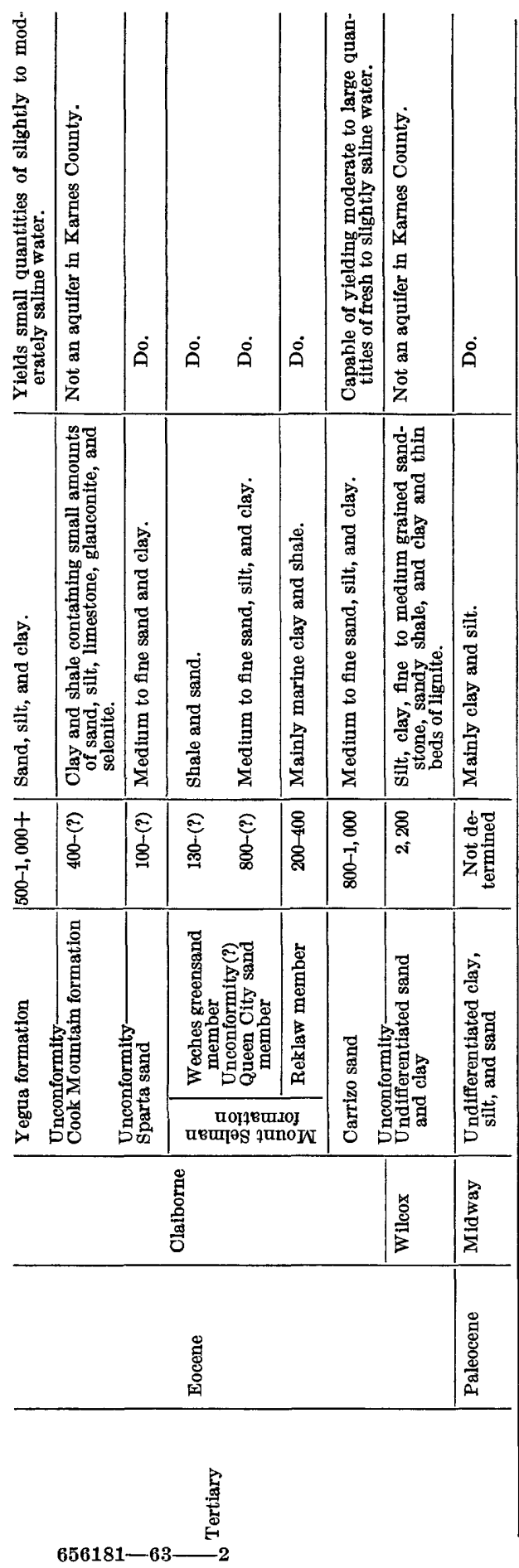
throws of from a few to several hundred feet. Most of the oil fields in the county are on structures associated with faulting.

The Gulf Coastal Plain was submerged during much of Cenozoic time. In Paleocene time the sea advanced, and the Midway deposits were laid down on the sea floor. After Midway time, deposits were laid down in lagoons and embayments or along the seashore and in the sea. The sediments were deposited as detrital material at or near the oscillating shoreline. During the later part of the Tertiary period, the sea withdrew from the region; since then, it has been above sea level. In much of the area beds of volcanic ash and tuff were deposited at various times in the Tertiary. Late in Pliocene time, after faulting and uplift, gravel and silt were spread over the land surface. Erosion then lowered the plain to the altitude of the present hilltops and divides. The gravel capping most of the hills and ridges is the remnant of flood-plain deposits laid down on the beveled surface of the older rocks. The lower and broader terraces are underlain by gravel, sand, and silt of Quaternary age.

\section{GEOLOGIC FORMATIONS AND THE OCCURRENCE OF GROUND WATER}

The water-bearing formations in Karnes County are being replenished continually by a small part of the precipitation on their outcrop areas. Most of the rainfall in and near Karnes County runs off in streams, evaporates, or is transpired by vegetation. Water that reaches the zone of saturation moves slowly through the rocks until it is discharged through some natural outlet, is intercepted by wells, or escapes by slow movement into overlying beds downdip from the outcrop. Most of the formations in the county must have contained salty water at one time, either because they were deposits in the sea or in brackish-water zones near the sea, or because the sea flooded the area shortly after their deposition. In Karnes County some beds of sand downdip from the outcrop are filled with fresh water, indicating that fresh water absorbed by the sand at the outcrop moved downdip and flushed out the salty water. At present, most of the sand beds contain fresh water near the outcrop and, generally, for some distance downdip. Farther downdip the water contains more mineral matter, the saline water being only partly flushed. Still farther downdip, the beds contain connate water, presumably water trapped in the sediments when they were deposited (Winslow and others, 1957, p. 387).

In this report, water is classified according to its dissolved-solids content as follows (Winslow and Kister, 1956, p. 5): 


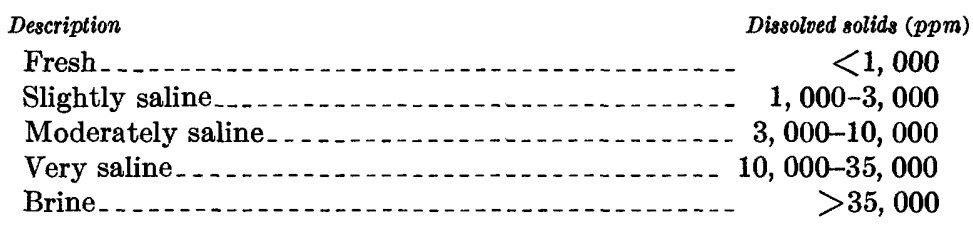

Water for public, irrigation, stock, and domestic supplies in the county is in either the fresh or slightly saline range. Slightly saline water, although undesirable, may be used for drinking with no apparent ill effects. Water containing as much as 3,000 ppm (parts per million) of dissolved solids has been used for supplemental irrigation. Experiments have indicated that $10,000 \mathrm{ppm}$ is the upper limit of salinity that can be tolerated by livestock (Smith and others, 1942, p. 15).

In general discussions of the yield of wells, the following rating, in gallons per minute (gpm), is used in this report:

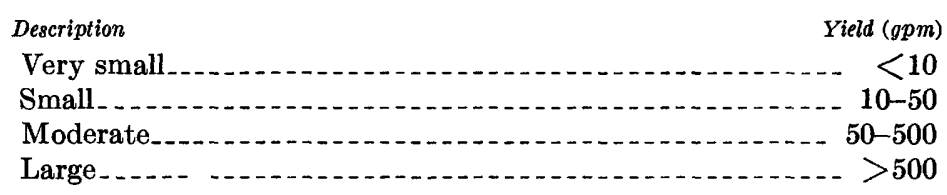

Water in the sandy outcrop areas generally is unconfined - that is, the surface of the zone of saturation, the water table, is in permeable materials and is subject only to atmospheric pressure.

Downdip from the outcrop, ground water in sandy formations commonly is confined by relatively impermeable overlying strata. Although the confining beds generally are regarded as impermeable, water may move very slowly even through clays. (See Winslow and others, 1957, p. 387.) Confined water is water under sufficient pressure to rise in tightly cased wells above the top of the aquifer. If the altitude to which water rises is greater than the altitude of the land surface, flowing wells result. The confined water is called artesian water whether or not it flows from wells.

The rocks of Tertiary and Quaternary age underlying Karnes County are mainly sandstone and sand interbedded with clay. Although all are saturated, only the sandy beds yield water freely to wells. The water table is at or near the surface in the valleys and as much as 100 feet below land surface along the interstream divides.

\section{TERTIARY STSTEM}

PALEOCENE BERIES

MIDWAY GROUP, UNDIFFERENTIATED

Rocks of the Midway group are the oldest Tertiary rocks in southcentral Texas. The Midway lies unconformably on rocks of Late 
Cretaceous age and unconformably below the Wilcox group. The Midway is at a depth of more than 5,000 feet along the Wilson County line. It dips toward the Gulf of Mexico at an average rate of more than 200 feet per mile. The group, composed mainly of clay and silt, contains thin beds of sand near the top. The thickness of the Midway in Karnes County was not determined. Interpretation of electric logs indicates no fresh or slightly saline water in or below the Midway group.

\section{EOCENE SERIES}

WHCOX GROUP, UNDIFFERENTIATED

Rocks of the Wilcox group, which unconformably overlie the Midway, do not crop out in Karnes County, but are penetrated in deep oil wells and oil-test holes. The base of the Wilcox group dips toward the Gulf of Mexico at a rate of more than 200 feet per mile. In Karnes County the Wilcox is composed of thinly bedded silt, clay, fine- to medium-grained sandstone, sandy shale and clay, and thin beds of lignite. The top of the Wilcox is at a depth of about 3,300 feet in the northeast corner of the county, where the group is about 2,200 feet thick. The chemical analysis of water from well A-22 and interpretation of electric logs indicate that the Wilcox group contains only moderately to very saline water.

\section{CLAIBORNE GROUP}

The Claiborne group consists of an alternating series of marine and continental strata. Each change from sand to clay indicates a change in the depositional environment. The sands indicate episodes of continental deposition; the fossiliferous clays indicate marine deposition; and the brown lignites indicate deposition in swamps (Sellards and others, 1932, p. 610). The Claiborne group includes the Carrizo sand, the Mount Selman formation, the Sparta sand, and the Cook Mountain and Yegua formations.

CARRIZO SAND

The Carrizo sand ovelies the Wilcox group unconformably; the top of the Carrizo is about 2,500 feet below land surface in the northeast corner of Karnes County. The formation crops out in a northeastward-trending belt 2 to 5 miles wide in the northern and north western parts of Wilson County (Anders, 1957, p. 13), but it does not crop out in Karnes County. The Carrizo dips toward the coast at an average rate of about 170 feet to the mile. Driller's and electric logs indicate that the Carrizo sand in Karnes County is composed of medium to fine sand, silt, and clay. Plate $4, A-A^{1}$ and $C-C^{1}$, shows that the Carrizo is about 1,000 feet thick near the Wilson County line. In northwestern Karnes County where, the Carrizo is nearest 
the surface, the formation consists mostly of coarse material and contains only a small amount of clay. Downdip near the Goliad County line where the top of the Carrizo is about 7,000 feet deep, interpretation of electric logs indicates that it contains considerably more clay than it does updip near the Wilson County line.

The Carrizo sand contains the deepest fresh to slightly saline water known in Texas. The fresh water in the formation in most of Wilson County and all Karnes County is under artesian pressure, which is enough in Karnes County to cause wells to flow. In southeastern Wilson County and western Karnes County, the hydraulic gradient of the confined water in the Carrizo sand is about 4 feet per mile in the direction of dip. The gradient elsewhere in the area probably is similar. Interpretation of electric logs and chemical analyses of samples of water from the formation indicates that the greatest depth of fresh to slightly saline water in the Carrizo sand is more than a mile below the land surface in southwestern Karnes County. The factors affecting the ability of the formation to yield water to wells are discussed on page GQ22.

MOUNT SELMAN FORMATION

The Mount Selman formation is subdivided into three membersthe Reklaw, Queen City sand, and Weches greensand.

\section{Reklaw member}

The Reklaw member conformably overlies the Carrizo sand in Karnes County. It does not crop out in the county, but it is present in the subsurface in the northwestern part at depths of about 2,800 feet. The rocks dip southeastward. In Karnes County, the Reklaw is composed mainly of marine clay and shale. Its thickness ranges from about 200 to 400 feet (pl. $4, A-A^{\prime}$ ). The Reklaw is distinguishable on electric logs in areas where the underlying and overlying formations contain sand; farther downdip, where the materials in the formations are more nearly alike, the Reklaw cannot be distinguished readily from the overlying deposits. The Reklaw is not an aquifer in Karnes County.

\section{Queen City sand member}

The Queen City sand member overlies the Reklaw member conformably. It does not crop out in Karnes County, but is present throughout the county in the subsurface at a depth of about 2,000 feet in the northwestern part. Interpretation of electric and drillers' logs indicates that the Queen City in northwestern Karnes County is composed of medium to fine sand, silt, shale, and clay. In the southeastern part of the county, where the Queen City sand member is more than 5,000 feet below land surface, it consists mainly of 
silt and clay. It is 800 feet thick near the Wilson County line. Interpretation of electric logs indicates that the Queen City does not contain fresh or slightly saline water in the county.

Weches greensand member

The Weches greensand member, the upper most member of the Mount Selman formation, overlies the Queen City sand member conformably. It does not crop out in Karnes County, but is present in the subsurface at depths ranging from about 1,400 to more than 5,000 feet ( pl. 4, $A-A^{\prime}$ and $C-C^{\prime}$ ). The Weches is composed of fossiliferous glauconitic sand and shale and is about 100 feet thick where it crops out in Wilson County. Interpretation of electric logs of wells in northwestern Karnes County indicates that the Weches is predominantly clay and is about 130 feet thick.

The member appears to thicken somewhat downdip, but the apparent increase in thickness may be due to misinterpretation of electric logs, at least in part, because of the decrease in sand in the overlying and underlying rocks. The Weches greensand member is not an aquifer in the county.

SPARTA SAND

The Sparta sand conformably overlies the Mount Selman formation. It does not crop out in Karnes County, but occurs in the subsurface at depths ranging from about 1,200 to more than 5,000 feet. Interpretation of electric logs indicates that in northwestern Karnes County the Sparta is about 100 feet thick and consists of fine sand and clay. The Sparta is predominantly sand in the northwest half of the county; farther downdip the sand grades into clay. The Sparta sand contains no fresh or slightly saline water in the county.

COOK MOUN'TAIN FORMATION

The Cook Mountain formation unconformably overlies the Sparta sand. It does not crop out in Karnes County, but is at depths of about 400 feet below land surface along the Wilson County line, where it is about 400 to 450 feet thick. It thickens downdip southeastward. It consists of fossiliferous clay and shale that contains a few lenses of sandstone and limestone and small amounts of glauconite and selenite. Interpretation of electric logs indicates that the Cook Mountain is not an aquifer in the county.

YEGUA FORMATION

The uppermost formation of the Claiborne group, the Yegua, often referred to as the "Cockfield" (Sellards and others, 1932, p. 666), unconformably overlies the Cook Mountain formation. The upper part of the Yegua crops out along the north half of the Wilson County 
line (pl. 1). The Yegua dips toward the coast at about 155 feet per mile. It is composed of beds of medium to fine sand, silt, and clay, which generally weather light red and tan. Deussen (1924, p. 78) reported that on the San Antonio River, about 1,000 feet below the crossing 4 miles south of Poth $(6$ miles northwest of county line of U.S. Highway 81 in Wilson County), the Yegua consists of brown clay, gray plastic shale, and a lens of yellow indurated sand. The Yegua contains small amounts of gypsum, and, according to Lonsdale (1935, p. 41), contains beds of lignite and limestone. It thickens from about 500 feet along the Wilson County line, where part of the formation is missing, to more than 1,000 feet downdip (pl. 4, $A-A^{\prime}$ and $C-C^{\prime}$ ). The Yegua is much finer grained downdip and not distinguishable readily on electric logs.

Generally, the Yegua yields small quantities of slightly to moderately saline water. In some areas it yields moderate quantities of fresh water.

\section{JACKSON GROUP, UNDIFFERENTIATED}

The Jackson group in Texas includes all Eocene strata above the Claiborne group. In this report the group has not been divided into formational units. It lies conformably above the Yegua and consists mainly of shallow-water marine and beach deposits of sand, clay, and tuff. Some of the beds of sand and clay contain lignitic material. The Jackson crops out in a broad belt, ranging in width from 4 to 10 miles, along and near the entire Wilson County line and dips gulfward at an average rate of 150 feet per mile (pl. 1 and pl. 4, $\left.A-A^{\prime}\right)$. The Jackson, which is about 900 feet thick at its surface contact with the Catahoula tuff that overlaps it, thickens downdip. It is about 2,400 feet below land surface near the Goliad County line.

The lower part of the Jackson group is composed predominantly of clay, bentonitic clay, and silt. Thin sand and ashy-sand strata separate some of the beds of clay and silty clay, and locally the lower part consists largely of sandy strata. The lower part yields small quantities of slightly to moderately saline water to wells that tap it at depths less than 1,000 feet.

The upper part of the Jackson group is composed mainly of beds of tuffaceous sand interbedded with bentonitic clay. Locally, some of the sandstone and clay beds are fossiliferous. Volcanic ash was contributed in large amounts to the sediments at various times during the Eocene epoch. Some of the volcanic ash is composed of medium-grained glass shards, large enough to be seen with the naked eye. In a few places the interstices between the grains of sand and silt are partly filled by carnotite and small amounts of other uranium minerals (Eargle and Snider, 1957, p. 17-26). 
The upper part of the Jackson group yields very small to moderate quantities of water to wells. Generally the water that is less than 1,000 feet below land surface is fresh to slightly saline, but some wells yield moderately saline water. B-61, an irrigation well, and D-50, one of the Karnes City municipal wells, may tap the Jackson group in part.

\section{OLIGOCENE(?) SERIES}

FRIO CLAY

The Frio clay has not been differentiated in Karnes County because of lithologic similarity with the overlying Catahoula tuff with which it has been included in the geologic sections. The Frio does not crop out in Karnes County because it is overlapped by the Catahoula; however, it crops out 8 miles southwest of the Karnes County line in northwestern Live Oak County. Where exposed in Live Oak County, it occupies a position between the Jackson group and the Catahoula tuff. In the subsurface the Frio lies unconformably upon the sands of the Jackson group. In Karnes County a layer of sand, conglomerate, and coarse detritus marks the upper contact of the Frio with the tuffaceous and ashy beds of the Catahoula (Sellards and others, 1932, p. 705). The Frio is composed of clay, sand, and sandy silt. The clay is bentonitic and slightly calcareous. Its thickness is reported to be about 200 feet in southern Karnes County. The Frio clay is not an aquifer in the county.

\section{MIOCENE(?) SERIES}

Catahodla tuFF

In Karnes County the Catahoula tuff unconformably overlaps the Frio clay and the upper part of the Jackson group. The formation crops out in a belt that ranges in width from about 3 miles in the northeastern part of the county to about 10 miles in the southwestern part. The part of the contact between the Jackson and Catahoula that is represented by a solid line on plate 1 has been mapped in detail and is located more accurately than the part represented by a dashed line. The average dip of the base of the Catahoula tuff in Karnes County is about 120 feet per mile. The Catahoula consists predominantly of tuff, tuffaceous clay, sandy clay, bentonitic clay, and discontinuous lenses of sandstone. The formation also contains thin beds of lignite and a few beds of limestone. Some ash beds are interbedded with bentonitic clay. Conglomerate, irregularly distributed throughout the formation, contains chunks of scoriaceous lava, pebbles of other igneous rocks, opalized wood, irregular masses of chalcedony, quartz, and chert. Interpretation of drillers' and electric logs indicates that beds of sand and gravel are present many miles downdip. The Catahoula is about 700 feet thick at its contact with the over- 
lying Oakville sandstone. The exact thickness of the Catahoula in the subsurface was not determined because it cannot be distinguished on electric logs from the underlying Frio clay, which is included with it on the geologic sections. Both formations thicken in the southern part of the county. Generally, the beds of sand and conglomerate are not more than 10 feet thick at the outcrop, though interpretation of electric logs indicates that some water-bearing zones, mainly sand or sand and conglomerate interbedded with clay, are nearly 100 feet thick (pl. 4, $A-A^{\prime}$ and $C-C^{\prime}$; pls. 6, 7).

The Catahoula tuff is one of the principal aquifers in Karnes County because it is the only shallow source of fresh to slightly saline water in its area of outcrop. Most of the municipal supply for Karnes City and part of the supply for Kenedy is obtained from wells tapping the Catahoula tuff. Five irrigation wells obtain part or all of their water from the Catahoula.

\section{MIOCENE SERIES}

OAKVILLE SANDSTONE

The Oakville sandstone, the principal aquifer in Karnes County, unconformably overlies and partly overlaps the Catahoula tuff. In some areas the contact of the Catahoula and the Oakville cannot be distinguished by electric logs because relatively thick beds of sand near the top of the Catahoula are similar to those in the Oakville. The outcrop, 8 miles wide in the northeastern part of the county, broadens to 11 miles along the San Antonio River and narrows to 7 miles in the southern part of the county (pl. 1). The base of the Oakville dips gulfward an average of 85 feet per mile. In Karnes County the Oakville is composed of crossbedded medium- to finegrained sand and sandstone and sandy, ashy, and bentonitic clay beds. Where the full section is present, the Oakville ranges in thickness from about 500 feet in southern Karnes County to 800 feet in the east-central part of the county (pl. 4, $A-A^{\prime}$ and $C-C^{\prime}$ ).

The Oakville sandstone yields large quantities of fresh to slightly saline water to some irrigation wells and to the municipal wells at Runge and Kenedy. Small quantities of fresh to slightly saline water are obtained from many domestic and stock wells. The thin beds of sand yield only small supplies of moderately saline water about 5 miles southwest of Kenedy.

\section{MIOCENE(?) SERIES}

LAGARTO CLAY

The Lagarto clay lies unconformably above the Oakville sandstone in a northeastward-trending belt in Karnes County (pl. 1). Because unaltered Lagarto clay is poorly exposed, its surface contact with the Oakville was mapped by differences in soils. The soil derived 
from the Oakville is residual dark-gray to dark-brown loam, which contains a large quantity of organic matter. Where the Lagarto is exposed, the beds of clay are reddish brown; no similar reddish-brown clay was found in the Oakville. Thick beds of sand, similar to those in the Oakville, make identification of the Lagarto difficult on electric logs. A prominent sand body, having a maximum thickness of about 40 feet, is well exposed about 2 miles southesat of Runge. This sand extends for about 10 miles from the San Antonio River to Nordheim in Dewitt County.

The Lagarto consists of clay and sandy clay that contains many calcareous nodules and intercalated beds of sand and sandstone. In general the beds of sand are most common near the outcrop and are replaced progressively by beds of clay downdip. At places the clay is capped by a bed of sand and gravel or by calcareous sandstone. No sharp distinction between the Oakville sandstone and Lagarto clay is shown on the geologic sections because of the large amount of clay in the Oakville (as much as 50 percent locally) and the large amount of sand in the Lagarto (as much as 40 percent locally). At the downdip edge of the outcrop in Goliad County, the Lagarto is about 500 feet thick. The thickness of the formation in Karnes County has not been determined, but it probably is about 500 feet where the full section of the formation is present. The dip is southeastward, ranging from 20 to 40 feet per mile.

The Lagarto yields small to moderate quantities of fresh to slightly saline water to many wells for domestic, stock, irrigation, and municipal supply. Water from the Lagarto generally is less mineralized than that from the Oakville.

\section{PIIOCENE SERTES GOLIAD SAND}

The Goliad sand overlies the Lagarto clay unconformably. It is difficult to distinguish the sand beds in the two formations; the contact in some areas is arbitrarily defined as the base of the first clay that contains grains of coarse sand. The soil developed on the Goliad bears a marked resemblance to the reddish-brown soil of the Lagarto clay. The Goliad crops out in several areas in southern and southeastern Karnes County (pl. 1). The formation dips and thickens coastward. The Goliad is reported to attain a maximum thickness of 500 feet in southeastern Goliad County, but its maximum thickness in Karnes County is about 100 feet. The Goliad consists predominantly of sand and sandstone interbedded with clay and gravel. The basal bed of sandstone, which is as much as 50 feet thick in places, contains clay and gravel. The gravel deposits include chert and quartz pebbles and calcareous fragments, which probably are redepos- 
ited caliche. The white color of the caliche is characteristic of the Goliad in the area of outcrop. The Goliad is, in most places, above the regional water table and contains very little water.

\section{TERTIARY(?) SYSTEM \\ PLIOCENE(?) SERIES \\ INTERSTREAM SAND AND GRAVEL DEPOSITS}

Most of the divides on the higher parts of the Gulf Coastal Plain are remnants of an ancient plain. The name "Uvalde gravel" has been applied to the covering deposits-remnants of a formation that consisted of coarse and fine gravel. The interstream deposits lie unconformably on beds ranging in age from Late Cretaceous to middle Pliocene. In most places the original unit has been eroded to residual gravel, either loose or embedded in caliche. Some remnants consist of thin sheets of flint gravel. In Wilson County the Uvalde gravel occurs in a zone extending several miles on either side of the San Antonio River and Cibolo Creek.

In Karnes County sand and gravel are found on the tops of hills in many places. One rather large deposit extends from a point 7 miles east-southeast of Gillett to a point 7 miles south-southeast. The interstream deposits dip gently gulfward as do the underlying older formations. Because the deposits cap the hills and spread down their sides, a result of erosion and weathering, the maximum thickness is not determined readily. Deussen $(1924$, p. 107) reported a thickness of 20 feet in Karnes County. Anders (1957, p. 18) states that the Uvalde gravel is in most places less than 2 to 5 feet thick in Wilson County. The interstream deposits are as much as 30 feet thick in Karnes County. Locally, the deposits resemble materials found in the Goliad sand. Boulders and cobbles are interbedded with coarse sand. The interstream deposits are not aquifers in Karnes County. For that reason and because they are thin and difficult to distinguish in the field, they are not differentiated on the geologic map (pl. 1) or the geologic sections.

\section{QUATERNARY SYSTEM}

\section{PLEISTOCENE AND RECENT SERIES}

ALIUVIUM

Scattered alluvial terrace deposits found along many of the larger streams and creeks in Karnes County are composed of fine sand, silt, clay, and some gravel. The alluvium ranges in thickness from 0 to 30 feet. It is not a major source of water in Karnes County and is not differentiated from the underlying deposits on the geologic map (pl. 1) and sections. 


\section{AQUIFER TESTS}

Six aquifer tests were made in Karnes County (fig. 2) to determine the ability of some beds of sand that contain fresh and slightly saline water to transmit and store water. The data from the pumping tests were analyzed by the Theis recovery method (Theis, 1935, p. 519-524) and the Theis nonequilibrium method as modified by Cooper and Jacob (1946, p. 526-534).

The results of the Karnes County tests and a test at Pettus in Bee County are shown in table 3.

TABLE 3.-Results of aquifer tests

\begin{tabular}{|c|c|c|c|c|c|}
\hline Well & Owner & $\begin{array}{l}\text { Length of } \\
\text { well screen } \\
\text { or slotted } \\
\text { casing in } \\
\text { pumped } \\
\text { well (feet) }\end{array}$ & Formation tapped & $\begin{array}{l}\text { Field co- } \\
\text { efficient of } \\
\text { transmissi- } \\
\text { bility (gpd } \\
\text { per ft) }\end{array}$ & $\begin{array}{l}\text { Coefficient } \\
\text { of storage }\end{array}$ \\
\hline $\mathrm{H}-30$ and $\mathrm{H}-31$ & $\begin{array}{l}\text { United Gas Pipe- } \\
\text { line Co. }\end{array}$ & 40 & $\begin{array}{l}\text { Oakville sandstone } \\
\text { and (or) Lagarto }\end{array}$ & 5,000 & 0.000074 \\
\hline $\begin{array}{l}\text { E-39 and E-40. } \\
\text { D-48 and } D-49 \\
\text { D-50 }\end{array}$ & $\begin{array}{l}\text { City of Runge. } \\
\text { Karnes City }\end{array}$ & $\begin{array}{l}34 \\
40 \\
93\end{array}$ & $\begin{array}{l}\text { Oakville sandstone.... } \\
\text { Catahoula tuffi-..... } \\
\text { Catahoula tuff and }\end{array}$ & $\begin{array}{r}10,000 \\
1,400 \\
2,100\end{array}$ & $\begin{array}{r}.00024 \\
.00004 \\
-.0-\end{array}$ \\
\hline G-20, G-22, and G- & City of Kenedy & 62 & $\begin{array}{l}\text { Jackson group. } \\
\text { Oakville sandstone }\end{array}$ & 14,000 & .00013 \\
\hline E-20 and E-21........ & $\begin{array}{l}\text { Mrs. Ernest Yanta } \\
\text { and Henry } \\
\text { Hedtke. }\end{array}$ & 61 & -....do_....... & 8,000 & .00011 \\
\hline Pettus, Bee County. & $\begin{array}{l}\text { Stanolind Oil \& } \\
\text { Gas Co. Recy- } \\
\text { cling Plant. }\end{array}$ & 150 & do do & 11,000 & \\
\hline
\end{tabular}

The ability of an aquifer to transmit water is measured by its coefficient of transmissibility. The field coefficient of transmissibility is defined as the amount of water in gallons per day that will pass through a vertical strip of aquifer having a width of 1 foot and a height equal to the thickness of the aquifer under a hydraulic gradient of 1 foot per foot at the prevailing aquifer temperature. The coefficient of storage of an aquifer is defined as the volume of water it releases from or takes into storage per unit surface area of the aquifer per unit change in the component of head normal to that surface; that is, the volume of water released by a column of the aquifer having a cross-sectional area of 1 square foot when the head is lowered 1 foot. The coefficients from these tests represent only the sand zones tested in the area in which they were tested and should not be used to predict yield or drawdown in untested areas. However, the order of magnitude of the coefficients generally are about what may be expected in a particular formation.

No tests were made of wells tapping the Carrizo sand, but tests made in Wilson County suggest that the transmissibility of the Carrizo 
is much greater than that of any of the other formations tested in Karnes County.

\section{GROUND-WATER DEVELOPMENT}

\section{PRESENT DEVELOPMENT}

\section{WTTHDRAWALS}

It is estimated that Karnes County has 1,000 water wells, and that the quantity of ground water discharged by these wells in 1957 averaged about 1.7 million gpd (gallons per day). Of this amount, about 350,000 gpd was produced from the Carrizo sand; the remainder was from the younger water-bearing formations. Ground water was the only source of municipal and domestic supplies of water for about 18,000 persons and was the source for much of the irrigation and stock supplies. It is estimated that the amount of ground water used for municipal, domestic, irrigation, and stock supplies in 1957 averaged about $700,000,175,000,650,000$, and $175,000 \mathrm{gpd}$, respectively. Figure 5 shows the monthly pumpage from the municipal-supply wells at Falls City, Karnes City, Kenedy, and Runge based on data reported by city officials.

\section{CHANGES IN WATER LEVEL}

Table 4 compares the water levels in selected wells in Karnes County in 1936 or 1937 with the water levels in the same wells in 1956 or 1957 . Of the 81 wells listed in the table, water levels declined less than 8 feet in 41 and rose less than 8 feet in 24 . Of the other wells, water levels declined 8.5 to 36.6 feet in 12 and rose from 9.1 to 24 feet in 4 .

The head in the aquifers in Karnes County responds mainly to changes in rates of withdrawal of ground-water. However, the changes in water level in some of the wells in table 4 may be due to changes in the physical condition of the well caused by deepening, partial plugging, or leaking casing. Thus, the data probably are suggestive but are not controlled exclusively by changes in withdrawal rates and amount of ground water in storage.

Changes in water levels in wells may be due in part to local changes in withdrawal rates as many of the wells are used frequently every day. Thus, a substantial rise in water level may indicate that withdrawals from the measured well or nearby wells were greater during the period immediately preceding the 1936-37 measurement than during the period immediately preceding the 1956-57 measurement. A substantial decline may indicate that withdrawals from the measured well were greater during the period immediately preceding the 1956-57 measurement. 

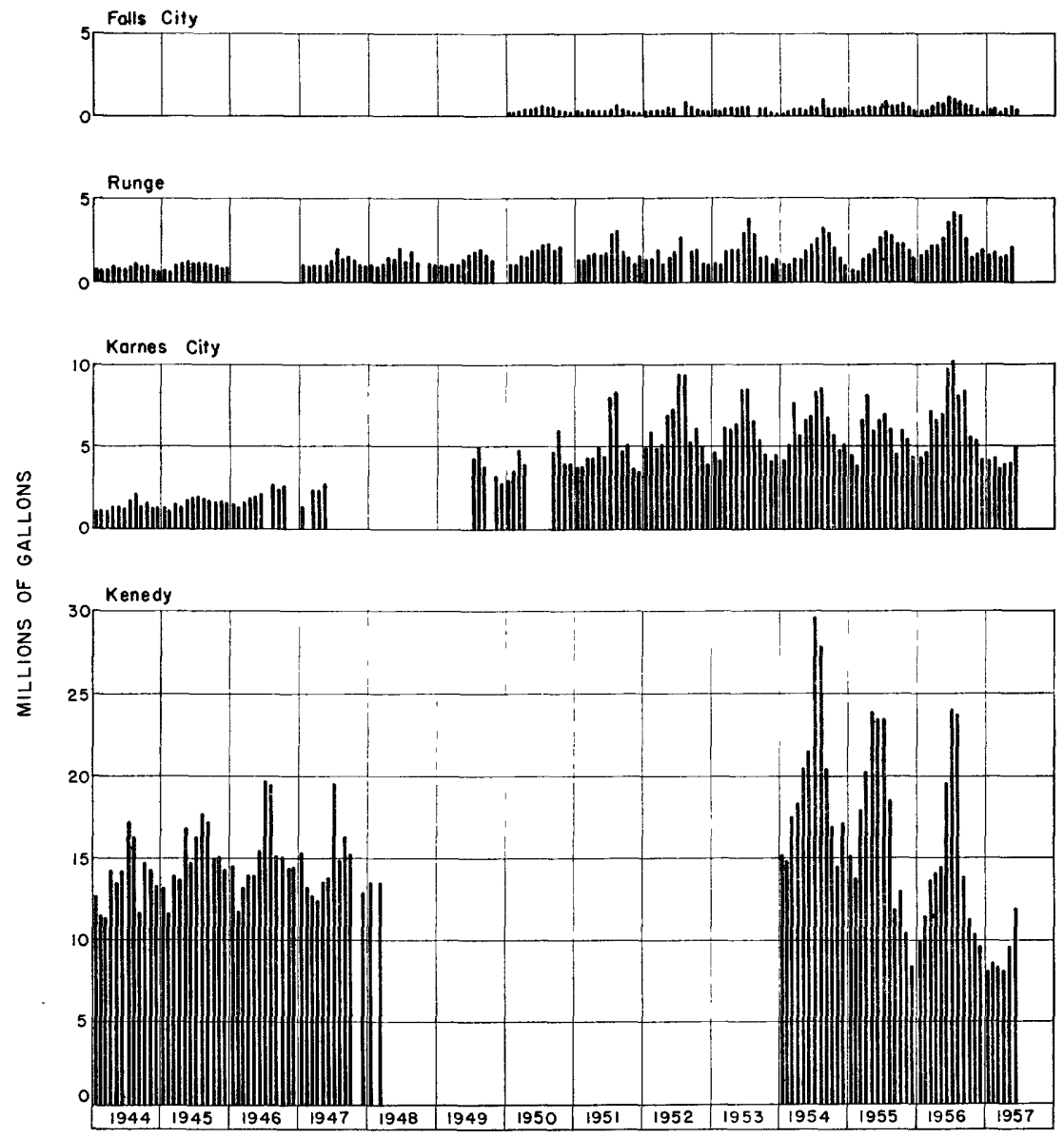

Figure 5.-Monthly pumpage from municipal wells at Falls City, Runge, Karnes City, and Kenedy, Karnes County. (Records are incomplete.)

Most of the water-level records show changes in artesian pressure rather than changes in the thickness of saturated material. Only a very small change in the total amount of ground water in storage is indicated despite the drought of 1950-56.

\section{POTENTIAL DEVELOPMENT}

The potential development of ground water in Karnes County is small in comparison with that in Wilson County where the Carrizo sand is closer to the surface and in Goliad County where the Goliad and younger formations crop out. However, the potential rate of withdrawal is large compared to the rate of withdrawal in 1957. In favorable locations, wells less than 1,000 feet deep yield as much as 
TABLE 4.-Water levels in selected wells in 1936 or 1937 and water levels in the same wells in 1955 or 1956, Karnes County, Tex.

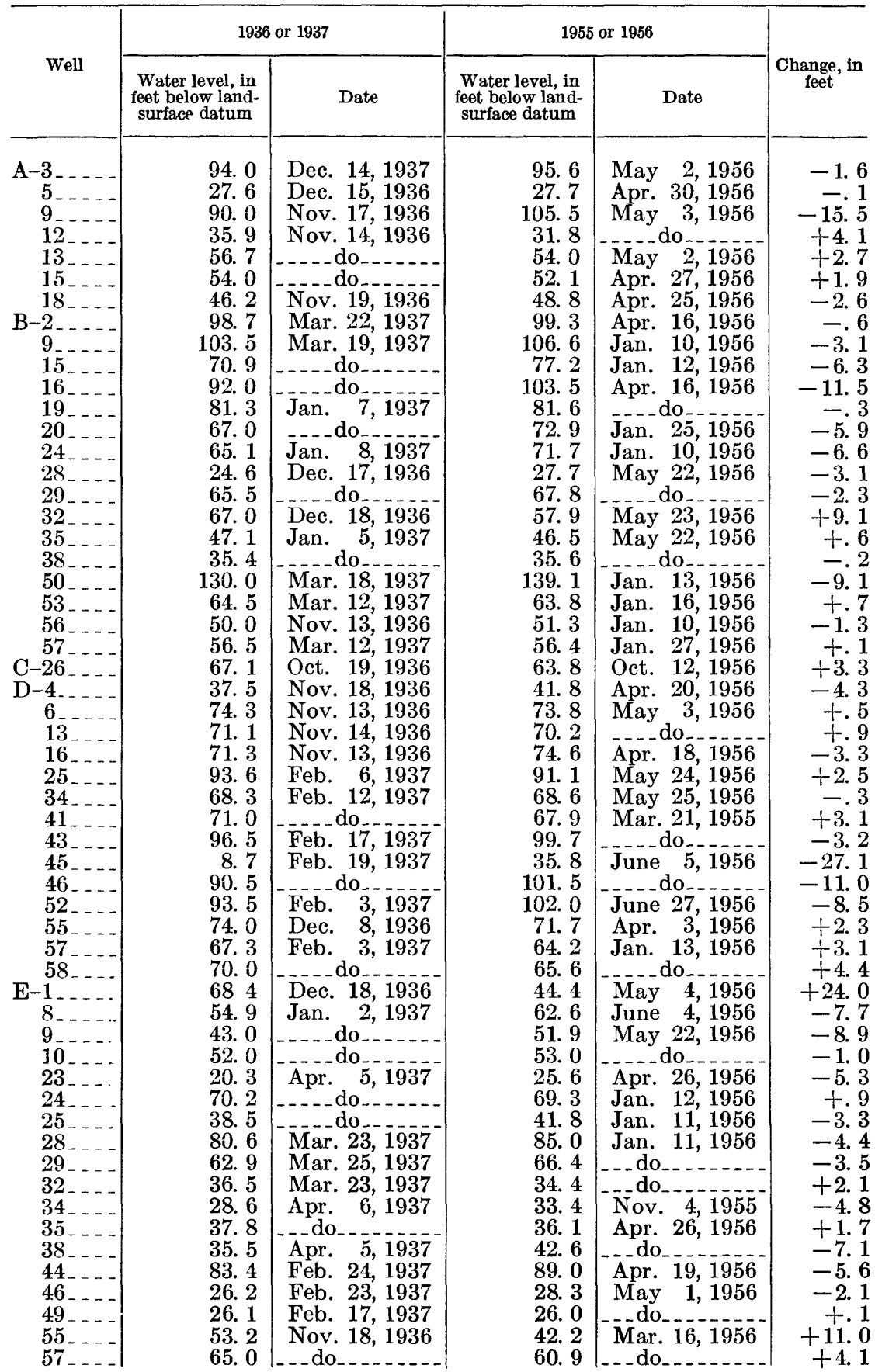


TABLE 4.-Water levels in selected wells in 1936 or 1937 and water levels in the same wells in 1955 or 1956, Karnes County, Tex.-Continued

\begin{tabular}{|c|c|c|c|c|c|}
\hline \multirow{2}{*}{ Well } & \multicolumn{2}{|c|}{1936 or 1937} & \multicolumn{2}{|c|}{1955 or 1956} & \multirow{2}{*}{$\begin{array}{c}\text { Change, } \\
\text { in feet }\end{array}$} \\
\hline & $\begin{array}{l}\text { Water level, in } \\
\text { feet below land- } \\
\text { surface datum }\end{array}$ & Date & $\begin{array}{l}\text { Water level, in } \\
\text { feet below land- } \\
\text { surface datum }\end{array}$ & Date & \\
\hline 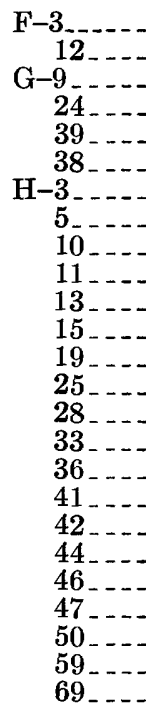 & $\begin{array}{r}85.2 \\
96.3 \\
94.4 \\
80.0 \\
152.5 \\
148.1 \\
99.0 \\
77.3 \\
87.0 \\
36.7 \\
31.6 \\
30.2 \\
37.7 \\
68.4 \\
141.7 \\
34.7 \\
44.6 \\
33.9 \\
11.4 \\
38.0 \\
10.5 \\
78.7 \\
61.0 \\
58.0 \\
134.3\end{array}$ & 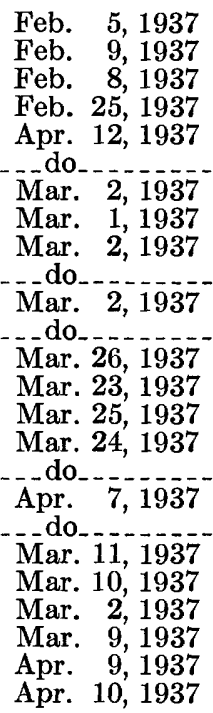 & $\begin{array}{r}83.6 \\
113.4 \\
96.3 \\
68.7 \\
149.6 \\
142.0 \\
114.3 \\
77.5 \\
89.3 \\
42.9 \\
34.8 \\
45.1 \\
44.3 \\
73.4 \\
140.7 \\
36.8 \\
48.3 \\
37.4 \\
19.2 \\
57.2 \\
47.1 \\
84.9 \\
61.8 \\
55.7 \\
139.2\end{array}$ & 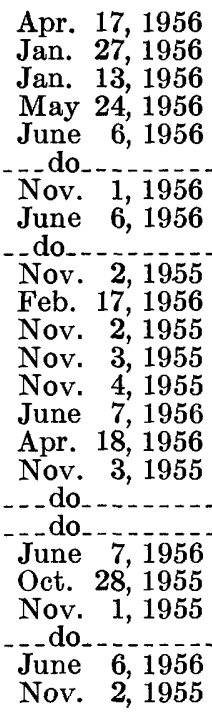 & $\begin{array}{r}+1.6 \\
-17.1 \\
-1.9 \\
+11.3 \\
+2.9 \\
+6.1 \\
-15.3 \\
-.2 .2 \\
-2.3 \\
-6.2 \\
-3.2 \\
-14.9 \\
-6.6 \\
-5.0 \\
+1.0 \\
-2.1 \\
-3.7 \\
-3.5 \\
-7.8 \\
-19.2 \\
-36.6 \\
-6.2 \\
-.8 \\
+2.3 \\
-4.9\end{array}$ \\
\hline
\end{tabular}

$600 \mathrm{gpm}$, and deeper wells tapping the Carrizo sand in part of northwestern Karnes County may yield as much as 1,000 gpm. Water supplies suitable for watering stock can be obtained almost anywhere in the county within a depth of 200 feet, but the water in several places may be too saline for domestic use. The quality of water differs from place to place, but it may be estimated in many places by comparing the analyses of samples from nearby wells of similar depth.

The development of ground water in a given area is limited by the cost of the water relative to its value. Two major factors affecting the unit cost of water are the initial cost of the well and the cost of pumping; the cost of the well is related to its depth and diameter, and the cost of pumping is related mainly to the pumping lift. Although wells tapping the Carrizo sand are capable of yielding large quantities of water in Karnes County, the cost of constructing wells deep enough to tap it, 4,000 to 5,000 feet deep, is prohibitive for most uses. Moderate to large supplies are available from some of the other water-bearing formations in the county, but several wells will be 
required for large supplies; the cost of construction and the great pumping lifts may prohibit their economic development.

Pumping lifts are related to the hydraulic properties of the aquifer and casings, the rate of withdrawal, and the number and spacing of wells. Figure 6 shows that for a given pumping rate the drawdown

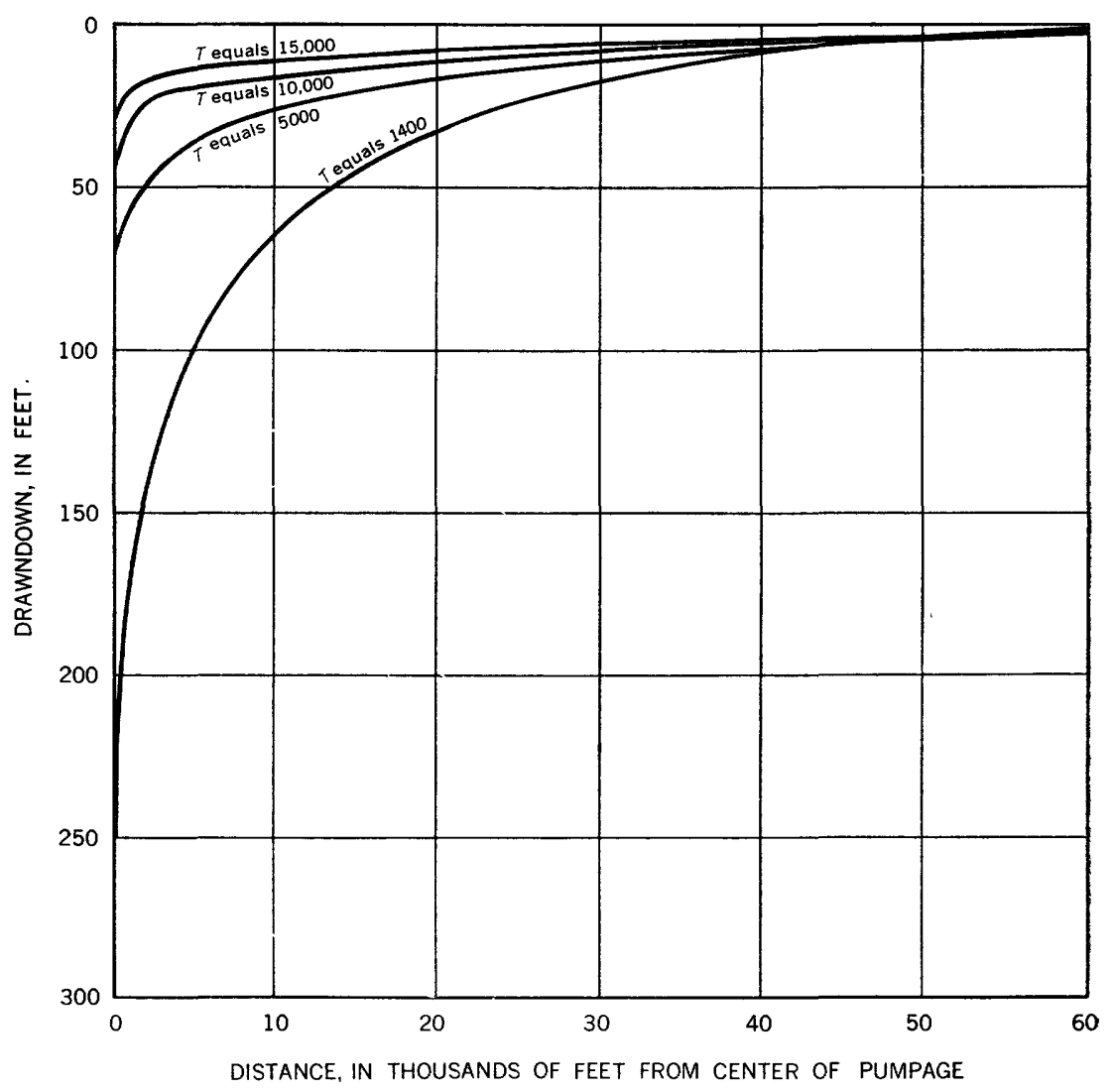

Figure 6.-Relation between drawdown and transmissibility in an aquifer of infinite areal extent. (Assume coefficient of storage $=0.00012$; tim $\theta=1$ year; and discharge $=300 \mathrm{gpm} . T=$ coefficient of transmissibility.)

of water levels is inversely proportional to transmissibility and distance from the point of withdrawal. The range of transmissibilities shown in figure 6 is typical of the water-bearing formations younger than the Carrizo sand in Karnes County. Drawdown is directly proportional to the pumping rate. The addition of each pumping well increases the pumping lift of each nearby well.

Drawdowns in artesian wells in the county are less than those indicated in figure 6 , when the effects of pumping reach the recharge area of the aquifer which is generally the outcrop. The wells intercept $656181-63-3$ 
water that otherwise would be discharged by evapotranspiration principally where the formations crop out in stream valleys resulting in little or no decline of water levels along the outcrop. Thus, the outcrop acts as a line source of recharge (Guyton, 1942, p. 47; Theis, 1941, p. 734-737). If withdrawals exceed the amount of water intercepted, water levels will decline in the artesian wells at the same slow rate as they do in the recharge area under water-table conditions. Figure 7 shows, for example, that the drawdown 10,000

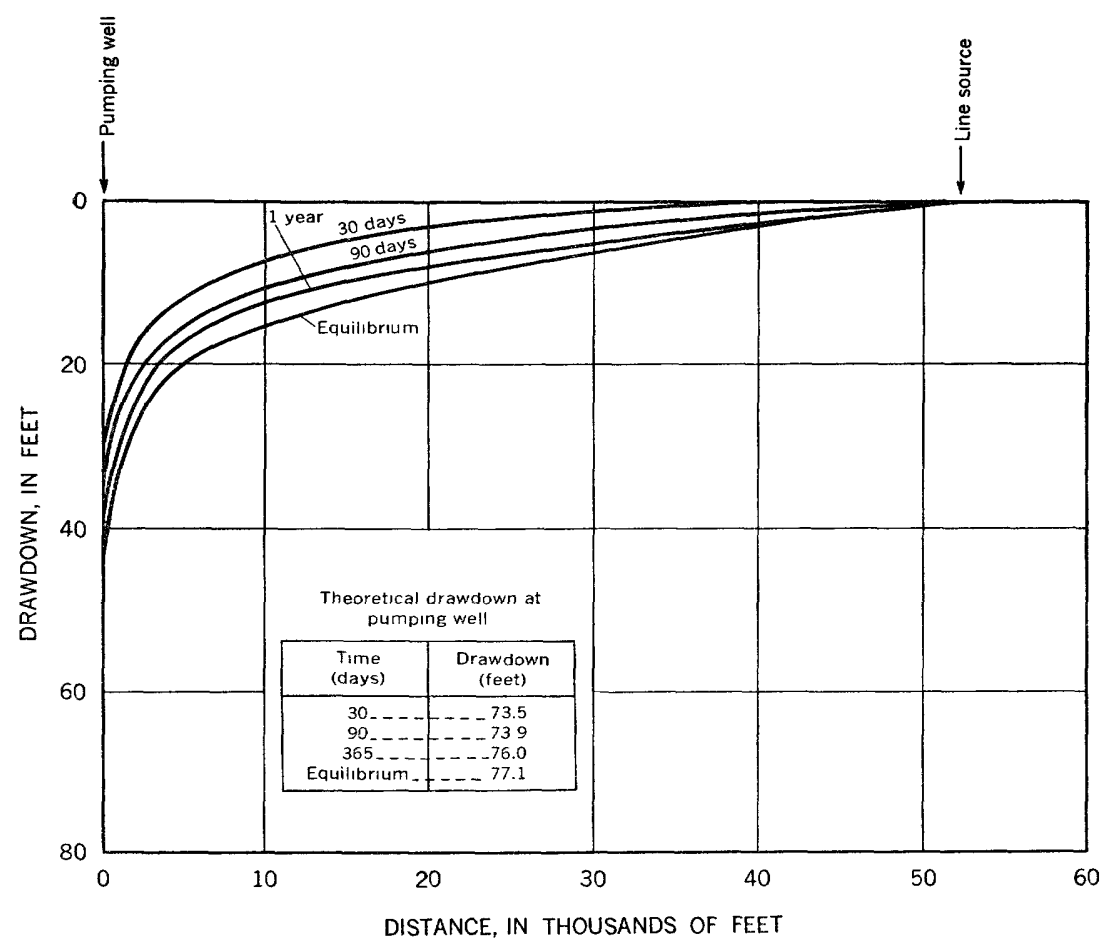

FIGURE 7.-Theoretical drawdown along a profile between a pumping well and a line source (aquifer outcrop). (Assume: line source is 10 miles from the pumping well; coefficient of transmissibility $(T)=10,000$; coefficient of storage $=0.00012$; and discharge $=300 \mathrm{gpm}$.)

feet from a well pumping 300 gpm would be about 13 feet after 1 year if the well were 10 miles downdip from the outcrop. The drawdown in an infinite aquifer having the same transmissibility $(10,000$ gpd per ft) and discharge would be about 16 feet after 1 year of pumping. (See fig. 6.) The drawdown would be less if the well were nearer to the recharge area and greater if the well were farther from the recharge area.

The relative productivity of wells of similar size and construction in different areas is largely a function of the transmissibility, which is a 
function of the permeability and thickness of the water-bearing material. Interpretation of aquifer tests and subsurface geologic data indicate that materials of the Oakville sandstone and Lagarto clay are more permeable than those of the Catahoula tuff, Jackson group, and Yegua formation. With this in mind, the geologic map (pl. 1) and the map showing the thickness of sands containing fresh to slightly saline water (pl. 8) are useful in determining the relative productivity of different areas in the county. For example, the most productive area, excluding the area underlain by fresh water in the Carrizo, is the southeast corner of the county, where sands in the Oakville and Lagarto are thickest. Wells in this area may yield as much as $600 \mathrm{gpm}$. The maximum yield from wells in favorable areas underlain by the Catahoula, Yegua, and Jackson should be considerably less-perhaps 50 to $400 \mathrm{gpm}$.

Potential development of ground water in the county is related to the quantity of water in storage and the potential rates of recharge to and discharge from the ground-water reservoir. The quantity of fresh to slightly saline water in storage above a depth of 1,000 feet is estimated to be about 30 million acre-feet assuming that the saturated sand has a porosity of 30 percent.

Streamflow records and soil textures indicate that recharge to the ground-water reservoir from infiltration at the land surface probably is small. The potential rate of recharge, however, probably exceeds the rate of discharge as of 1957; if reservoirs are built in the county on the San Antonio River or its tributaries, the potential rate of recharge may be increased substantially.

Even though a large part of the water in storage may be impracticable to recover, discharge could be increased by several times the 1957 rate of about 2,000 acre-feet per year without depleting the available storage appreciably for many decades.

Detailed investigations of the hydrologic characteristics of aquifers and the chemical quality of ground waters should precede any large development of ground water in the county.

\section{SURFACE-WATER DEVELOPMENT}

The San Antonio River and Cibolo Creek are the only perennial streams in the county. For the 31-year period of record from April 1925 through September 1956, the San Antonio River near Falls City had a maximum flow of 47,400 cfs (cubic feet per second) on September 29, 1946; a minimum flow of 15 cfs on June 27-28, 1956; and an average flow of $288 \mathrm{cfs}-208,500$ acre-feet per year (U.S. Geological Survey, 1958, p. 227). Plate 9 shows the monthly mean discharge of the San Antonio River at the gaging station near Falls City, Tex. (about 3 miles southwest of Falls City, fig. 1), where it 
has a drainage area of 2,071 square miles. For the 26-year period from November 1930 through September 1956, Cibolo Creek had a maximum flow of 33,600 cfs on July 6,1942 ; had no flow on July $30-31$ and August 4-22, 1956; and an average flow of $106 \mathrm{cfs}-76,740$ acre-feet per year (U.S. Geological Survey, 1958, p. 229). Plate 10 shows the monthly mean discharge of Cibolo Creek at the gaging station near Falls City, Tex., at a point about 51/2 miles east-northeast of Falls City, which is about 9 miles above its junction with the San Antonio River (fig. 2). The drainage area above the station is 831 square miles.

Development of the surface-water resources is regulated by the State. To provide for the equitable distribution and use of surface water, the Texas Board of Water Engineers has authority to issue water permits, which specify the maximum rate of withdrawal, the amount of land that may be irrigated, and the time of year when the water may be withdrawn. Water permits for Karnes County allow 1,837 acre-feet of water to be withdrawn annually from the San Antonio River to irrigate 909 acres. The maximum allowable rate of withdrawal from the San Antonio River in the county is $37.5 \mathrm{cfs}$. No permits have been issued for diverting water from Cibolo Creek in Karnes County, but in Wilson County, where the perennial flow of Cibolo Creek originates, permits have been issued to allow 585 acre-feet of water to be withdrawn each year to irrigate 503 acres at a maximum rate of withdrawal of $15 \mathrm{cfs}$. On July 30,1956 , Cibolo Creek near Falls City ceased flowing for the first time since the gaging station was installed in 1931 and probably for the first time since the land was settled in 1854. Most of the flow of the creek was intercepted by upstream pumping, but some water was consumed by plants and some evaporated. Part of the water may have been lost by influent seepage.

Ground water in the shallow sands in the interstream areas moves generally toward the streams. Streamflow records indicate little or no gain in base flow across the county; it appears, therefore, that ground water moving toward the streams is consumed by evapotranspiration in the valleys.

\section{QUALITY OF WATER}

Data on chemical quality of ground water in this report are compiled from 95 analyses by the Geological Survey, from 245 analyses by the Works Progress Administration (WPA) working under the supervision of the Bureau of Industrial Chemistry, University of Texas (Shafer, 1937), and from interpretations and correlations of electric $\log$ s by the writer. Methods of analysis used by the WPA do not conform to present-day standards of accuracy of methods by the 
Geological Survey; hence the analyses by the Geological Survey are the most reliable. Although somewhat inaccurate, analyses by the WPA show the general chemical character of the water. Analyses of 340 samples from 312 wells are available.

Interpretation of chemical quality of water from electric logs based on changes in both the resistivity curves and the self-potential curve of electric logs gives a rough approximation of the mineralization of the water. The interpretations largely are a matter of judgment and experience (Jones and Buford, 1951, p. 115-139), but were facilitated by a comparison between chemical analyses and electric logs in a few places.

Water from the San Antonio River has not been sampled systematically in Karnes County, but the quality probably is similar to that 15 miles downstream, where samples were collected daily from the San Antonio River at Goliad from October 4, 1945 through September 29, 1946, according to Hastings and Irelan (1946).

Classification by the content of dissolved constituents, as shown on page G33, is only one of several criteria for judging the suitability of water for various uses. The following discussion of other criteria pertains to the most common uses of water in Karnes County.

Tolerances of individuals for drinking water of various quality ranges widely, but no one in Texas is known to use water continually that contains more than $3,000 \mathrm{ppm}$ of dissolved solids. Livestock have survived on water containing as much as $10,000 \mathrm{ppm}$, though water of considerably better quality is necessary for maximum growth and reproduction. The maximum concentrations of constituents considered important by the U.S. Public Health Service $(1946$, p. 13) for drinking water used on common carriers preferably should not exceed the concentrations that are shown in the following table.

$\begin{array}{ll}\text { Constituent } & \begin{array}{c}\text { Concen } \\ \text { tration } \\ (p p m)\end{array} \\ \text { Magnesium }(\mathrm{Mg}) & 125 \\ \text { Shloride }(\mathrm{CI}) & 250 \\ \text { Fluate }\left(\mathrm{SO}^{4}\right) & \\ \text { Dissolved solids should not exceed } 500 \text { ppm. However, if water of } \\ \text { such quality is not available, a dissolved-solids content of 1,000 } \\ \text { ppm may be permitted. }\end{array}$

These limitations were set primarily to protect travelers from digestive upsets. Most people can drink water continually that contains substantially higher concentrations than the suggested limits, though some new users may suffer ill effects from the water until their digestive systems become accustomed to the change. 
Water containing chloride in excess of $300 \mathrm{ppm}$ has a salty taste, water containing magnesium and sulfate in excess of concentrations recommended in the standards tends to have a laxative effect, and water containing fluoride in excess of about $1.5 \mathrm{ppm}$ may cause the teeth of children to become mottled (Dean and others, 1935). Concentrations of about $1.0 \mathrm{ppm}$ of fluoride, however, reduce the incidence of tooth decay. Water containing more than about 45 ppm nitrate has been related by Maxcy (1950, p. 271) to the incidence of infant cyanosis (methemoglobinemia or "blue baby" disease) and may be dangerous for infant feeding. A high nitrate content of water also may be an indication of pollution from organic matter. A well yielding water containing more nitrate than other nearby wells should be sampled and the water tested for bacterial content if the water is to be used for domestic supplies. Animal wastes from privies and barnyards commonly are the source of pollution, and such wastes will increase the nitrate content of the water.

Municipal water supplies in Karnes County are substandard because better water is not readily available. However, the regular users seem to be accustomed to the water and suffer no ill effects from it. The chloride content for all public supplies and many of the domestic supplies exceeds $250 \mathrm{ppm}$. The chloride content of water from municipal wells ranges from $315 \mathrm{ppm}$ at Runge to $900 \mathrm{ppm}$ at Kenedy. The concentrations of magnesium and sulfate in most of the samples of water are within the limits recommended in the standards. Samples from 2 municipal wells (D-47 and D-49) in Karnes City contained more than $1.5 \mathrm{ppm}$ of fluoride. Only 2 other wells (C-1 and C-34) that supply drinking water yield water having a fluoride content greater than $1.5 \mathrm{ppm}$. Samples from 7 of 14 wells, for which the fluoride content was determined, contained more than $1.5 \mathrm{ppm}$ of fluoride. The water from three of the wells is not used for drinking, however, results of 67 determinations of nitrate show only 2 samples (wells $\mathrm{F}-20$ and $\mathrm{H}-63$ ) that contained more than $45 \mathrm{ppm}$. The San Antonio River contains no undesirable concentrations of dissolved mineral matter that would restrict its use as drinking water.

Certain concentrations of magnesium, calcium, silica, iron, and manganese in water affect its use for industrial and domestic needs. The characteristic of water called hardness is caused almost entirely by calcium and magnesium. As the hardness increases, soap consumption for laundering increases and incrustations (boiler scale) accumulate more rapidly on boilers, pipes, and coils. Hardness equivalent to the carbonate and bicarbonate is called carbonate hardness; the remainder of the hardness is called noncarbonate hardness. Two methods commonly are used to soften large quantities of water: The lime or lime-soda ash process, which in addition to softening reduces 
the mineralization; and the zeolite process, which involves the exchange of calcium and magnesium in the water for sodium in the exchange material. Carbonate hardness may be removed most economically by using lime as the precipitant.

Silica also forms hard scale in boilers. The deposition of scale increases with the pressure in the boiler. The following table shows the maximum allowable concentrations of silica for water used in boilers, as recommended by Moore (1940, p. 263).

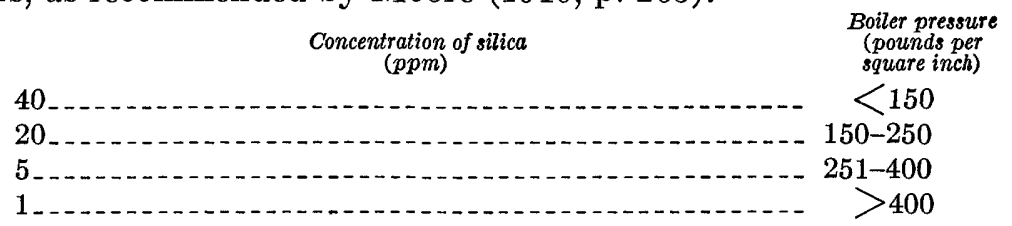

Oxidation of dissolved iron and manganese in water forms a reddishbrown precipitate that stains laundered clothes and plumbing fixtures. The staining properties of water containing these minerals are especially objectionable in some manufacturing processes. Water containing more than $0.3 \mathrm{ppm}$ of iron and manganese together is likely to cause appreciable staining.

Water from Karnes County may be compared with the following commonly accepted standard of hardness for public and industrial supplies (U.S. Geological Survey, 1959, p. 14).

$\begin{array}{ll}\text { Water classification } & \begin{array}{r}\text { Hardness as } \mathrm{CaCO}_{3} \\ (p p m)\end{array} \\ \text { Soft } & <60 \\ \text { Moderately hard } & \end{array}$

The water analyses indicate that water from the San Antonio River and most of the ground water is hard or very hard. The public supplies of Karnes City and Falls City are notable exceptions-both having wells that yield soft water. The concentrations of silica in samples ranged from 1.9 to $96 \mathrm{ppm}$. Although the amount of silica was determined in relatively few samples, the data suggest that the concentration of silica might be a major consideration in obtaining industrial water supplies. Only 4 of 39 determinations showed a content of iron and manganese together exceeding $0.3 \mathrm{ppm}$. Silica, manganese, and iron were not reported for samples from the San Antonio River.

Water becomes less suitable for irrigation as the salinity, sodium (alkali), and boron hazards increase. The salinity hazard commonly is measured by the electrical conductivity of the water, which is an indication of the concentration of dissolved solids. The conductivity in micromhos per centimeter at $25^{\circ} \mathrm{C}$ is about $1 \frac{11}{2}$ times the dissolved solids content in parts per million, though the relation is somewhat 
variable. The sodium-adsorption ratio (SAR) is an index of the sodium hazard of an irrigation water and is defined by the following equation, the concentration of the ions being expressed in equivalents per million:

$$
\mathrm{SAR}=\frac{\mathrm{Na}^{+}}{\sqrt{\frac{\mathrm{Ca}^{++}+\mathrm{Mg}^{++}}{2}}} .
$$

Percent sodium is another term used to express sodium hazard. It is determined as follows, all ions being expressed in equivalents per million.

$$
\text { Percent sodium }=\frac{\mathrm{Na}^{+} \times 100}{\mathrm{Na}^{+}+\mathrm{Ca}^{++}+\mathrm{Mg}^{++}+\mathrm{K}^{+}} .
$$

High concentrations of the bicarbonate ion in irrigation water may have a deleterious effect on both plants and soil. An excessive quantity expressed as residual sodium carbonate (RSC) is determined as follows, all ions being expressed in equivalents per million:

$$
\mathrm{RSC}=\left(\mathrm{CO}_{3}-+\mathrm{HCO}_{3}-\right)-\left(\mathrm{Ca}^{++}+\mathrm{Mg}^{++}\right) .
$$

The boron hazard is measured by the concentration of dissolved boron in the water.

The U.S. Salinity Laboratory Staff (1954) treated in detail the effects of quality of irrigation water on soils and crops in arid and semiarid climates. Wilcox (1955, p. 16), a member of the staff, reported that, with respect to salinity and sodium hazard, water may be used safely for supplemental irrigation if its conductivity is less than 2,250 micromhos per centimeter at $25^{\circ} \mathrm{C}$ and its $\mathrm{SAR}$ value is less than 14. The maximum safe values for percent sodium, RSC, and boron have not been determined for subhumid or humid climates; thus the following values for arid climates represent safe values, but not maximum safe values for the subhumid climate of Karnes County.

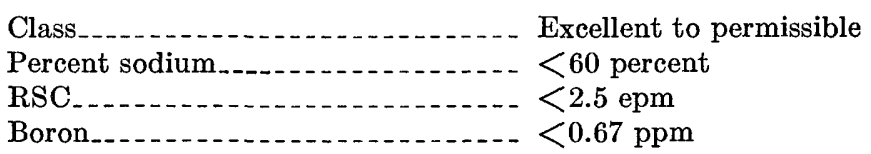

The standards for irrigation water are not strictly applicable to Karnes County, but they show which water is safe and which should be used with caution.

Of the 11 samples from wells used for irrigation in Karnes County, only one (well A-23) exceeded the limit for salinity hazard, and one (well G-2) exceeded the limit for sodium hazard for supplemental irrigation. Four samples (wells E-13, E-21, H-58, and H-68) were within all limits for an arid climate, and the other five exceeded one 
or more of the limits for an arid climate. Although the boron content of water from the San Antonio River was not determined, it is believed to be well within irrigation water standards. Water from the San Antonio River otherwise is considered to be of excellent quality for irrigation in Karnes County.

The quality of ground water in Karnes County is extremely variable. Within a single formation the quality of water in one strata may be considerably different from that in another strata. Within a single strata the quality may differ considerably from place to place. Because of the variations, the chemical characteristics of the water are not discussed by areas, formations, or depths, except in very general terms in previous sections of this report. The best prediction of the probable quality of water in a particular location can be obtained by examining the data on quality of water from nearby wells.

\section{SUMMARY OF CONCLUSIONS}

Public, industrial, and domestic water supplies in Karnes County depend solely on ground water, and irrigation and stock supplies depend on both ground and surface waters. Most of the ground water used in Karnes County in 1957 was of fair to poor quality; whereas, water from the San Antonio River is suitable in quality for most uses. Estimated ground-water withdrawals in 1957 averaged about 2.1 million gpd from about 1,000 water wells; however, about 80 percent of the water was withdrawn from 21 municipal and irrigation wells. Withdrawals from 1936 through 1957 have not affected water levels in wells appreciably. The greatest decline recorded was 36.6 feet, but water levels either rose or declined less than 8 feet in 69 of the 81 wells measured. The amount of surface water used was not determined, but water permits allow 1,837 acre-feet (about 1.6 million gpd) of water to be withdrawn from the San Antonio River in Karnes County.

About 70 million acre-feet of fresh to slightly saline ground water is stored in the county. About 40 million acre-feet is stored below a depth of 3,000 feet in the Carrizo sand in the northern and western parts of the county. The remainder is stored in younger formations throughout the county at depths less than 1,000 feet. Although it is impracticable to recover much of the stored water, the rate of withdrawal could be increased by several times over the 1957 rate (about 2,000 acre-feet per year) without depleting the available storage appreciably for many decades.

Recharge to the water-bearing formations probably is small, owing to unfavorable soil and topography, but probably it exceeds withdrawals in 1957. 
Potential well yields range from a few gallons per minute, where permeables are low and the water-bearing materials are thin, to as much as 1,000 gpm from wells tapping the full thickness of the Carrizo sand. Other principal water-bearing formations in their approximate order of importance are the Oakville sandstone, Lagarto clay, Catahoula tuff, Jackson group, and Yegua formation. Wells yielding enough water of a quality satisfactory for livestock can be finished at depths of less than 200 feet anywhere in the county. By referring to the maps in this report, favorable areas may be selected for developing moderate to large supplies of fresh to slightly saline water for other uses, through some such developments may not be feasible economically.

The water table in the divide areas slopes toward the streams, but records of streamflow show that very little or no ground water reaches the San Antonio River. The water is presumed to be discharged by evapotranspiration in the stream valleys.

The surface-water resources of Karnes County may be increased substantially by impounding stormflows. No firm plans have been made, however, to construct additional reservoirs on the San Antonio River or its tributaries. Surface reservoirs, if constructed, may increase ground-water recharge substantially.

\section{SELECTED REFERENCES}

Anders, R. B., 1957, Ground-water geology of Wilson County, Texas: Texas Board Water Engineers Bull. 5710.

Bailey, T. L., 1926, The Gueydan, a new Middle Tertiary formation from the southwestern Coastal Plain of Texas: Texas Univ. Bull. 2645.

Bloodgood, D. W., Patterson, R. E., and Smith, R. L. Jr., 1954, Water evaporation studies in Texas, Texas Agr. Ext. Service Bull. 787.

Broadhurst, W. L., Sundstrom, R. W., and Rowley, J. H., 1950, Public water supplies in southern Texas: U.S. Geol. Survey-Supply Water Paper 1070.

Cooper, H. H., Jr., and Jacob, C. E., 1946, A generalized graphical method for evaluating formation constants and summarizing well-field history: Am. Geophys. Union Trans., v. 27, p. 526-534.

Dale, O. C., Moulder, E. A., and Arnow, Ted, 1957, Ground-water resources of Goliad County, Texas: Texas Board Water Engineers Bull. 5711, 93 p. [p. 10.]

Dean, H. T., Dixon, R. M., and Cohen, Chester, 1935, Mottled enamel in Texas: Public Health Repts., v. 50, p. 424-442.

Deussen, Alexander, 1924, Geology of the Coastal Plain of Texas west of Brazos River: U.S. Geol. Survey Prof. Paper 126.

Eargle, D. H., and Snider, J. L., 1957, A preliminary report on the stratigraphy of the uranium-bearing rocks of the Karnes County area, south-central Texas: Texas Univ. Rept. Inv. 30.

Ellisor, A. C., 1933, Jackson group of formations in Texas with notes on Frio and Vicksburg: Am. Assoc. Petroleum Geologists Bull., v. 17, no. 11, p. 1293-1350. 
Follett, C. R., White, W. N., and Irelan, Burdge, 1949, Occurrence and development of ground water in the Linn-Faysville area, Hidalgo, County, Texas: Texas Board Water Engineers, duplicated report. $49 \mathrm{p}$.

Guyton, W. F., 1942, Results of pumping tests of the Carrizo sand in the Lufkin area, Texas: Am. Geophys. Union Trans., pt. 2, p. 40-48.

Hastings, W. W., and Irelan, Burdge, 1946, Chemical composition of Texas surface waters: Texas Board Water Engineers, duplicated report, $41 \mathrm{p}$.

Houston Geological Society, 1951, Western Gulf Coast: Am. Assoc. Petroleum Geologists Bull., v. 35, no. 2, p. 385-392.

Jones, P. H., and Buford, T. B., 1951, Electric logging applied to ground-water exploration: Geophysics, v. 16, no. 1, p. 115-139.

Knowles, D. B., and Lang, J. W., 1947, Preliminary report on the geology and ground-water resources of Reeves County, Texas: Texas Board Water Engineers, duplicated report, $87 \mathrm{p}$.

Lohman, S. W., 1949, Sedimentary facies of the Gulf Coast: Am. Assoc. Petroleum Geologists Bull., v. 33, no. 12, p. 1939-1997.

Lonsdale, J. T., 1935, Geology and ground-water resources of Atascosa and Frio Counties, Texas: U.S. Geol. Survey Water-Supply Paper 676.

Maxcy, K. F., 1950, Report on the relation of nitrate concentrations in well waters to the occurrence of methemoglobinemia in infants: Natl. Research Council Bull., Sanitary Eng. and Environment, app. D.

Moore, E. W., 1940, Progress report of the committee on quality tolerances of water for industrial uses: New England Water Works Assoc. Jour., v. 54, p. 263.

Renick, B. C., 1936, The Jackson group and the Catahoula and Oakville formations in a part of the Texas Gulf Coastal Plain: Texas Univ. Bull. 3619.

Sellards, E. H., Adkins, W. S., and Plummer, F. B., 1932, The geology of Texas, v. 1, Stratigraphy: Texas Univ. Bull. 3232.

Shafer, G. W., 1937, Records of wells, drillers' logs, and water analyses, and map showing location of wells in Karnes County, Texas: Texas Board Water Engineers, duplicated report, $73 \mathrm{p}$.

Smith, O. M., Dott, Robert A., and Warkentin, E. C., 1942, The Chemical analyses of the waters of Oklahoma: Oklahoma A. and M. Coll., Div. Eng. Pub. 52, v. 12.

Theis, C. V., 1935, The relation between the lowering of the piezometric surface and the rate and duration of discharge of a well using ground-water storage: Am. Geophys. Union Trans., pt. 2, p. 519-524.

- 1941, The effect of a well on the flow of a nearby stream: Am. Geophys. Union Trans., p. 734-737.

Weeks, A. W., 1945, Oakville, Cuero, and Goliad formations of Texas Coastal Plain between Brazos River and Rio Grande: Am. Assoc. Petroleum Geologists Bull., v. 29, no. 12, p. 1721-1732.

Wenzel, L. K., 1942, Methods for determining permeability of water-bearing materials, with special reference to discharging-well methods: U.S. Geol. Survey Water-Supply Paper 887, 192 p.

Wilcox, L. V., 1955, Classification and use of irrigation waters: U.S. Dept. of Agriculture Circ. 969, 19 p.

Winslow, A. G., Doyel, W. W., and Wood, L. A., 1957, Salt water and its relation to fresh ground water in Harris County, Texas: U.S. Geol. Survey WaterSupply Paper 1360-F, p. 375-407, 4 pls., 11 figs. 
Winslow, A. G., and Kister, L. R., 1956, Saline water resources of Texas: U.S. Geol. Survey Water-Supply Paper 1365, $105 \mathrm{p}$.

U.S. Geological Survey, 1958, Surface-water supply of the United States, 1956, pt. 8, Western Gulf of Mexico basins: U.S. Geol. Survey Water-Supply Paper 1442.

1959, Quality of surface waters of the United States, 1954, pts. 7-8, Lower Mississippi River basin and Western Gulf of Mexico basins: U.S. Geol. Survey Water-Supply Paper 1352.

U.S. Public Health Service, 1946, Drinking water standards: Public Health Repts., V. 61 , no. 11, p. 371-384.

U.S. Salinity Laboratory Staft, 1954, Diagnosis and improvement of saline and alkali soils: U.S. Dept. Agriculture Agr. Handb. 60. 


\section{INDEX}

\begin{tabular}{|c|c|}
\hline Page & $\mathbf{P a}$ \\
\hline$G_{4}$ & 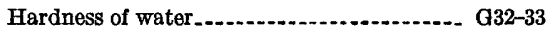 \\
\hline l terrace deposits....... & fferentiated_. \\
\hline lluvium & Ierentiated \\
\hline quifer tests, results & \\
\hline 2 & Karnes City, fluo \\
\hline 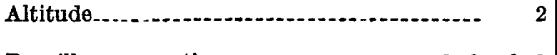 & $\begin{array}{l}\text { municipal wells } \\
\text { monthly pumpage from municipal wells.- } 23,24\end{array}$ \\
\hline n........ 8, 9 ; pl. 3 & precipitation. 7 \\
\hline & soft water from wells. .......... \\
\hline & Kenedy, chloride content of water from \\
\hline Y & municipal wells \\
\hline 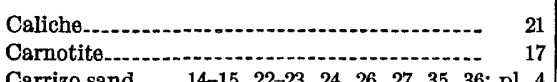 & $\begin{array}{l}\text { monthly pumpage from municipal we } \\
\text { water for municipal wells from Oak } \\
\text { sandstone }\end{array}$ \\
\hline
\end{tabular}

Carrizo sand 14-15, 22-23, 24, 26, 27,35, 36; pl. Catahoula tuff._............ 18-19, 29, 36; pls. 1, 4, 6, 7

Chalcedony................................. 18

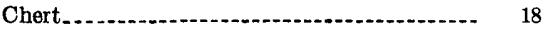

Cibolo Creek........................ 2, 21, 29, 30; pl. 10 Claiborne group............................... 14

Climatological stations, location ................

Coefficient cf storage of an aquifer, defined...-

Coefficient of transmissibility

Constituents in drinking water, maximum concentrations...........................

Cook Mountain formation.

Dip of formations.

Drawdowns in artesian wells

Drought in area.

Lagarto clay

19-20, 29, 36; pl. 1

Lignite.............................................. 17

Live Oak County, Frio clay

Location of area . .............................. 2

Midway deposits................................ 12

Midway group, undifferentiated............... 13-14

Mount Selman formation...................... 14,15-16

Queen City sand member................. 15-16

Reklaw member......................... 15; pl. 4

Weches greensand member............. 16; pl. 4

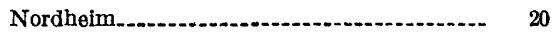

Oakville sandstone . ............... 19, 29, 36; pls. 1, 4

Objectives of investigation.................... 2

Oil, production

Panna Maria, oldest settlement.............. 3

Pebbles, chert................................ 20

quartz...................................... 20

Percent sodium, determination................ 34

Pettus, aquifer test............................ 22

Population

Precipitation .......................... 4, 6-9

Previous in vestigations......................... 4

Pumpage, monthly, from municipal-supply

18 wells.............................. 23, 24

Pumping tests.................................. 22

Purpose of investigation....................... 1

Quartz.

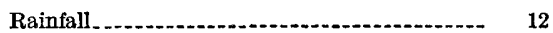

See also Precipitation.

Recharge to water-bearing formations........ $\quad 35$

Residual sodium carbonate, determination... $\quad 34$

Runge, chloride content of water from municipal wells ........................... 32

monthly pumpage from municipal wells.- 23,24

precipitation . ......................... 4, 6, 7, 9

temperature............................. 4

water for municipal wells from Oakville sandstone ......................... 19 
San Antonio River.......................... $17,19,20,21,29,30,31,32,33,35,36$; pl. 9

Selenite 16

Sodium-adsorption ratio, defined.

Soil, Goliad sand.

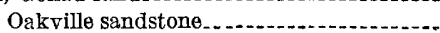

Sparta sand

Strike of formations.

Surface-water resources, development.

Temperature.

Towns.

Uranium ore, discovery

Uvalde gravel, Gulf Coastal Plain

Volcanic ash

Water, chemical quality

classification

$12-13,33$

concentrations of constituents _._._-_._-_. 31-35

from San Antonio River for irrigation....
Water-bearing formations, recharge to Page

Water-bearing properties of stratigraphic units.............................. 10-11

Water-level changes in selected wells.... 23-24, 25-26

Water table in divide areas.................. 36

Wells, for irrigation.................... 4, 18, 19, 34-35 municipal-supply........................... 23

potential yield

rating for yield ............................... 13

Wilcox group, undifferentiated............. 14

Wilson County, aquifer tests................ 22

Carrizo sand..................................... 14

fresh water.................................... 15

potential development of ground water--- 24

Uvalde gravel.............................. 21

water permits for diverting water from

Cibolo Creek....................... 30

$14,16-17,29,36$; pls. 1,4 